\title{
The Potential of Neurotrophic Factors for the Treatment of Parkinson's Disease
}

\author{
Aideen M. Sullivan* and André Toulouse \\ Department of Anatomy and Neuroscience, University College Cork, Cork \\ Ireland
}

\section{Introduction}

Parkinson's disease (PD) is the second most common neurodegenerative disorder, with an incidence of $1.5-2 \%$ in the population over 60 years of age, which increases significantly with advancing age (for reviews see de Lau \& Breteler, 2006; Toulouse \& Sullivan, 2008). Since the Western world is experiencing significant increases in life expectancy, the incidence of PD is steadily escalating. The financial and economical burden to society of the treatment and care of PD patients is substantial and increasing. Thus, research on the causes of this debilitating disease is critical, as is the development of new treatments.

PD is caused by progressive degeneration of the nigrostriatal (A9) dopaminergic pathway, which projects from the substantia nigra in the midbrain to the caudate-putamen (striatum) in the forebrain (Braak et al., 2003; Fearnley \& Lees, 1991; Hoehn \& Yahr, 1967; Olanow \& Tatton, 1999). The resulting loss of dopamine neurotransmission in the striatum causes the cardinal symptoms of the disease: tremor at rest, rigidity and bradykinesia. One of the pathological hallmarks of PD is the appearance of intracellular protein aggregates called Lewy bodies, which are found in the substantia nigra and other brain areas (for reviews see Forno, 1996; Gibb \& Lees, 1988). Lewy bodies are abnormal aggregates composed of $\alpha$ synuclein, ubiquitin and other proteins. Approximately 5\% of PD cases are caused by heritable genetic mutations, of which at least twelve have been identified (for review see Toulouse \& Sullivan, 2008). The remaining cases are sporadic and of unknown origin, although many theories have been proposed to explain the cause of dopaminergic neuronal death which occurs in $\mathrm{PD}$, such as environmental toxins, mitochondrial dysfunction with resulting oxidative stress, and inflammatory mechanisms (for reviews see Dauer \& Przedborski, 2003; Dawson \& Dawson, 2003; Fahn \& Cohen, 1992; Long-Smith et al., 2009).

At present there is no effective long-term therapy for PD. The most commonly-used treatment is administration of the dopamine precursor, levodopa, which replaces lost dopamine in the denervated striatum and relieves motor symptoms. Levodopa is generally administered in conjunction with an inhibitor of peripheral decarboxylase (carbide or benserazide), which has the effect of enhancing the central activity of levodopa and decreasing peripheral side-effects. Levodopa is successful in treating PD symptoms; however, it does not stop the ongoing neurodegeneration. Furthermore, about $50 \%$ of patients develop complications within the first five years of treatment, primarily severe motor fluctuations and dyskinesias (Freed et al., 2001; Hagell et al., 2002). Other current drug treatments include inhibitors of the dopamine breakdown enzymes catechol-O-methyl- 
transferase (tolcapone or entacapone) or monoamine oxidase-B (selegiline and rasagiline), and dopamine receptor agonists (bromocriptine, pergolide, pramipexole, ropinirole and others). Surgical methods involving ablation of deep brain structures such as the thalamus or pallidum, or deep brain stimulation of the subthalamic nucleus or pallidum, have also been used with good success, but these procedures are not widely-available or applicable for all patients. In summary, none of the current treatments provide safe and long-lasting relief from the symptoms and none have any effect on the progression of the disease. Much of the current research is aimed at developing new and novel therapies that will slow, halt or reverse the neurodegenerative process, rather than simply treating the symptoms of the disease. These include the use of antioxidants, anti-apoptotic agents, cell-based therapies and neuroprotective factors. Neurotrophic factors are a class of proteins that have the potential to be used as neuroprotectants in PD therapy.

\section{Dopaminergic neurotrophic factors}

One novel therapeutic strategy under investigation is the use of neurotrophic factors, which have the potential to slow down or halt the ongoing neurodegeneration in PD patients. These are secreted proteins that play critical roles in the developing nervous system, in the induction, specification, survival and maturation of developing neurones. Certain neurotrophic factors also act in the adult brain, to support and protect mature neuronal populations. Several of these factors have been investigated for their neurotrophic and protective effects on dopaminergic neurones. PD, being primarily caused by the degeneration of one neuronal population, the nigrostriatal dopaminergic projection, lends itself to neurotrophic factor therapy. The goal of this therapeutic approach is to apply a factor(s) which can halt or even reverse the progressive degeneration of nigrostriatal dopaminergic neurones, and which can be administered to patients in a safe, targetted and long-lasting manner. Some of the neurotrophic factors have potent effects on dopaminergic neurones, which render them good targets for novel therapeutics for PD. These include glial cell line-derived neurotrophic factor (GDNF), neurturin, growth/differentiation factor (GDF) 5, transforming growth factor (TGF) $\beta$, mesencephalic astrocyte-derived neurotrophic factor (MANF) and cerebral dopaminergic neurotrophic factor (CDNF).

\subsection{GDNF family of ligands (GFL)}

GDNF is the neurotrophic factor that has attracted the most interest in the field of PD research. GDNF is the prototypical member of the GFL family, which is composed of four factors - GDNF, neurturin, persephin and artemin. This family of neurotrophic factors is a subfamily of the TGF $\beta$ superfamily of proteins. These factors are secreted as precursors, in the form preproGFL, which undergo proteolytic cleavage within the extracellular space to release the active peptide. It has been reported that the prepro form of some neurotrophic factors are biologically active (Lee et al., 2001).

GDNF was isolated from a glial cell line in 1993, due to its ability to promote the survival of cultured dopaminergic neurones (Lin et al., 1993). Although GDNF was originally identified as a dopaminergic neurotrophic factor, subsequent studies have shown that it can act on a wide variety of neuronal types, including motor, noradrenergic, enteric, parasympathetic, sympathetic and sensory neurones (for reviews, see Airaksinen \& Saarma, 2002; Airaksinen et al., 1999; Aron \& Klein, 2011; Baloh et al., 2000; Bespalov \& Saarma, 2007). It also plays important roles in the developing kidney and in spermatogenesis. GDNF is expressed throughout the brain, as well as in peripheral tissues (Choi-Lundberg \& Bohn, 1995). 


\subsubsection{Signalling by GFLs}

Signalling by the four GFL proteins is mediated through the receptor tyrosine kinase, Ret, in combination with a second receptor that is unique to each of the four ligands (for reviews see Airaksinen \& Saarma, 2002; Airaksinen et al., 1999; Aron \& Klein, 2011). Each of the GFLs acts as a disulphide-linked homodimer, binding to two molecules of a specific glycosyl-phosphatidylinositol-anchored co-receptor, the GDNF family receptors a (GFRa), which are a family of transmembrane receptor proteins. GDNF binds preferentially to GFRa1, neurturin to GFRa2, persephin to GFRa3 and artemin to GFRa4. Binding of dimeric GFL to its GFRa results in recruitment of the Ret receptor, using a mechanism which involves lipid rafts. The resulting complex composed of GFL, GFRa and Ret activates the intracellular tyrosine kinase domain of Ret, triggering intracellular signalling cascades (for reviews see Airaksinen \& Saarma, 2002; Airaksinen et al., 1999; Sariola \& Saarma, 2003). Many signalling pathways are involved, including Ras-extracellular signal-regulated kinase (ERK), phosphoinositide 3-kinase (PI3K)-Akt, Src and phospholipaseC $\gamma$-protein kinase (PK)C. Activation of these pathways results in many diverse cellular changes, including neuronal survival. An alternative signalling pathway for GDNF and neurturin has also been identified, whereby each of these ligands can bind to the neural cell adhesion molecule (NCAM) in the absence of Ret (Cao et al., 2008; Paratcha et al., 2003; Sariola \& Saarma, 2003). The GDNF-NCAM complex can subsequently bind GFRa1, which leads to the activation of intracellular signalling pathways, involving focal adhesion kinase and Fyn kinase, both of which play roles in neuronal migration during development (Paratcha \& Ledda, 2008). In addition to NCAM, other cell adhesion molecules, such as integrin $\beta 1$ and N-cadherin, which are expressed on nigral dopaminergic neurones, may be involved in GDNF's actions on these cells during development (see Cao et al., 2010). GDNF, neurturin and artemin, but not persephin, have also been reported to act through a heparin sulphate proteoglycan, syndecan-3, a transmembrane protein which can mediate neurite outgrowth after binding to matrix-bound GFLs (Barnett et al., 2002; Bespalov et al., 2011).

The receptors Ret and GRF $\alpha 1$ are expressed at high levels on dopaminergic neurones of the adult rat substantia nigra (Glazner et al., 1998; Golden et al., 1998; Horger et al., 1998; Matsuo et al., 2000; Nosrat et al., 1997; Sarabi et al., 2001; Treanor et al., 1996; Trupp et al., 1996; Trupp et al., 1997; Widenfalk et al., 1997; Yu et al., 1998), while GRF 22 has been reported to be expressed in regions adjacent to these neurones (Horger et al., 1998). In the developing brain, both Ret and GRFa1 are expressed in the midbrain from E11.5 in the rat (Nosrat et al., 1997) and E10 in the mouse (Golden et al., 1999). Transcripts for both Ret and GFR $\alpha 1$ have been found in cultures of E18 rat mesencephalon (Eggert et al., 1999). A recent study by Cao and colleagues found that the expression of Ret protein in the developing rat substantia nigra was evident by E16 and peaked at P21 (Cao et al., 2010).

\subsubsection{Effects of GDNF in vitro}

GDNF has consistently been shown to promote the survival of dopaminergic neurones in vitro. In the study that first described GDNF, the protective effects of this factor on dopaminergic neurones in cultures of embryonic rat midbrain were reported (Lin et al., 1993). Another study reported similar results, with application of GDNF improving the survival of cultured midbrain dopaminergic neurones by 1.6-fold (Krieglstein et al., 1995). GDNF was also shown to induce the expression of the dopamine synthetic enzyme, tyrosine hydroxylase (TH), in fetal human and rat cortical cultures (Theofilopoulos et al., 2001) and 
promotes the morphological differentiation of dopaminergic neurones in vitro (Widmer et al., 2000). As well as enhancing the survival and differentiation of embryonic rat dopaminergic neurones, GDNF can protect these cells from specific toxins. Hou and colleagues found that GDNF could protect cultured dopaminergic neurones from the toxic effects of 1-methyl-4-phenylpyridinium ion (MPP+), after the toxin had been removed from the cultures (Hou et al., 1996). Genetically-engineered cells overexpressing GDNF have been shown to exert dose-dependent protective effects on cultured dopaminergic neurones against MPP+ toxicity (Ma et al., 2000). GDNF treatment has also been reported to reduce apoptosis in dopaminergic neurones cultured from embryonic rat (Clarkson et al., 1995; Sawada et al., 2000) and human (Clarkson et al., 1997) midbrain. Repeated treatment with GDNF from the time of plating was found to protect cultured embryonic rat dopaminergic neurones from the toxin 6-hydroxydopamine (6-OHDA), when this toxin was applied after nine days in vitro (Eggert et al., 1999). However, another study applied GDNF to similar cultures after four days in vitro, which was a day before they received 6-OHDA treatment, and found no protective effects (Kramer et al., 1999). A study reported that the neuroprotective effects of GDNF on dopaminergic neurones in vitro were dependent on cAMP signalling pathways (Engele \& Franke, 1996). GDNF has also been found to protect cultured dopaminergic neurones from lipopolysaccharide-induced degeneration, a model of neuroinflammation (Xing et al., 2010). Most of the above studies were conducted on embryonic day 14 (E14) rat midbrain, the time point at which dopaminergic neurones are undergoing their terminal mitotic divisions and are beginning to differentiate. An in vitro study showed that GDNF can also support nigrostriatal dopaminergic neurones during their period of natural developmental death, which occurs postnatally (Burke et al., 1998). Midbrain cultures may contain dopaminergic neurones of two origins, the nigrostriatal pathway, which degenerates in PD and the mesolimbic pathway, which is largely spared in this disease. Differential effects of GDNF treatment on nigrostriatal (A9) and mesolimbic (A10) dopaminergic neurones in vitro have been reported, whereby a single dose of GDNF selectively enhanced the survival of A9 cells, while repeated exposure to this factor only increased the survival of A10 cells (Borgal et al., 2007).

\subsubsection{Effects of neurturin in vitro}

A second factor of the GFL family, neurturin, was purified due to its survival-promoting effects on sympathetic neurones (Kotzbauer et al., 1996). It was found to have neurotrophic effects on developing dopaminergic neurones in vitro, similar in strength to those of GDNF (Akerud et al., 1999; Horger et al., 1998). Neurturin is expressed in the ventral midbrain and striatum during development (Horger et al., 1998). Neurturin also protects cultured motor neurones from degeneration and induces neuritic sprouting in spinal cord neurones in vitro (Bilak et al., 1999).

\subsubsection{Effects of persephin and artemin in vitro}

Persephin, a third member of the GFL family, has also been found to exert neurotrophic effects on midbrain dopaminergic neurones in vitro (Milbrandt et al., 1998) and in vivo (Akerud et al., 2002). This factor also has trophic effects on motor neurones (Milbrandt et al., 1998) and has not been extensively investigated for its clinical potential in PD. The fourth member of the GFL family, artemin, has survival-promoting effects on dopaminergic neurones in culture (Baloh et al., 1998) and in vivo (Cass et al., 2006), and also has potent 
actions on sensory neurones of the dorsal root ganglia (Baloh et al., 1998). Like persephin, artemin has not progressed into clinical trials for PD; however it has been tested as a therapeutic for neuropathy (Gardell et al., 2003). In contrast to GDNF and neurturin, artemin and particularly persephin appear to act primarily outside of the CNS, as their receptors are expressed at higher levels in the periphery.

\subsection{TGF $\beta$}

Some members of the TGF $\beta$ superfamily have potent neurotrophic and protective effects on dopaminergic neurones. The TGF $\beta$ superfamily is a large family of secreted polypeptide growth factors, which play diverse physiological roles. They are involved in the development, differentiation and maintenance of the nervous system. There are two branches of the TGF $\beta$ superfamily - the TGF $\beta$ / activin group and the bone morphogenetic protein (BMP) / GDF group (for reviews see de Caestecker, 2004; Hogan, 1996; Krieglstein et al., 2002; Mehler et al., 1997). TGF $\beta 3$, a member of the TGF $\beta$ / activin group, has neuroprotective effects on dopaminergic neurones in vitro and in vivo (for review, see Roussa et al., 2009). Treatment with TGF $\beta 2$ or TGF $\beta 3$ has been reported to have potent neuroprotective effects on cultured embryonic rat dopaminergic neurones (Poulsen et al., 1994; Unsicker et al., 1996). It has been hypothesized that the neurotrophic effects of GDNF on many types of neurones, including dopaminergic neurones, require the presence of TGFß3 (Krieglstein et al., 1998; Schober et al., 2007), which acts by recruiting the GFR $\alpha 1$ receptor to the membrane (Peterziel et al., 2002).

\subsection{GDF5}

Another member of the TGF $\beta$ superfamily of proteins, GDF5, is also being investigated for its therapeutic potential in PD. GDF5 (also known as BMP-14 or CDMP1) is a member of the BMP subfamily, which is the largest subgroup of the TGF $\beta$ superfamily, comprising at least 20 members. BMPs are involved in diverse physiological functions, including the development of the nervous system, where they play roles in early CNS patterning as well as in neural cell fate determination, differentiation, and survival (for reviews see Ebendal et al., 1998; Hall \& Miller, 2004; Mehler et al., 1997).

GDF5 mRNA and protein expression have been found in the embryonic, neonatal and adult rat brain (Krieglstein et al., 1995; O'Keeffe et al., 2004; Storm et al., 1994). GDF5 protein expression in the rat brain peaks at E14, the time at which dopaminergic neurones in the developing midbrain are undergoing terminal differentiation (O'Keeffe et al., 2004). GDF5 protein is also expressed in several regions of the adult rat brain, including striatum and midbrain (O'Keeffe et al., 2004).

\subsubsection{Signalling by GDF5 and other BMPs}

BMPs such as GDF5 are synthesised as large precursor proteins of approximately 400-500 amino acids, which contain an N-terminal region which is necessary for secretion of the protein, a prodomain which directs folding of the protein, and a C-terminal mature active peptide (for reviews, see Bragdon et al., 2011; Sieber et al., 2009). The active proteins are each composed of 50-100 amino acids and generally contain seven cysteine residues. Six of these cysteines form disulphide bonds and the seventh (which is not present in GDF3, GDF9 or BMP15) forms a disulphide bond with another monomer, to form the biologically-active dimeric molecule. The BMPs generally act as homodimers, although heteromeric complexes 
of BMP2/6, BMP2/7 and BMP2b/7 have been described (Little \& Mullins, 2009; Sieber et al., 2009). Many of the BMPs have been found to create complexes with their respective prodomains following release into the extracellular environment as active dimers (for review, see Bragdon et al., 2011). The soluble active form of each BMP is capable of diffusion away from its site of release, while the form that is complexed with its prodomain remains in the extracellular matrix, usually bound to fibrillins (Ramirez \& Rifkin, 2009; Sengle et al., 2008).

BMPs signal by binding to two types of transmembrane serine-threonine kinase receptors, type I and type II receptors, and subsequently activating intracellular signalling pathways which culminate in diverse cellular changes, many of which are dependent upon Smad protein-dependent gene transcription (for reviews, see Bragdon et al., 2011; de Caestecker, 2004; Ebendal et al., 1998; Kawabata et al., 1998; Massague, 1996; Miyazono, 1999; Nohe et al., 2004; Yamashita et al., 1996). Individual BMPs can signal through any of several type I receptors and type II receptors. GDF5 signals predominantly through the type I receptor BMPR1b and the type II receptor BMPR2 (Nishitoh et al., 1996). Each of the BMP receptors is composed of a short extracellular ligand-binding portion which contains 10-12 cysteine residues, a single transmembrane region, and an intracellular part which contains the serinethreonine kinase domain. The type I receptors contain a glycine-serine rich region (a 'GS box') within their cytoplasmic domain. This GS box is necessary for their activation and is not present in the type II receptors. The various BMPs bind to type I and type II receptors with differing affinities. The presence of a prodomain within a BMP protein complex appears to decrease binding to Type II, but not to Type I, receptors (Sengle et al., 2008). Upon binding of a BMP to its specific receptors, a multimeric complex is formed, of variable composition, but usually consisting of two type I and two type II receptors. The initial binding stage is to the type I receptor, which anchors the ligand to the membrane and facilitates subsequent binding to the type II receptor. This induces phosphorylation by the constitutively-active type II receptor kinase of serine residues within the GS box of the type I receptor, which stimulates intracellular signalling cascades, generally resulting in the activation of Smad proteins. Activated Smads can then translocate into the nucleus and affect transcription.

Smad proteins are divided into three subclasses: regulatory Smads (R-Smads; Smad-1, -5 and -8), common Smad (Co-Smad; Smad 4) and inhibitory Smads (I-Smads; Smad-6 and -7). During BMP signalling, the C-terminal region of a regulatory Smad (Smads 1, 5 or 8) is phosphorylated by the type I receptor, which activates the canonical Smad signalling pathway. Phosphorylation of an R-Smad induces it to bind to Smad 4, followed by nuclear translocation of this complex (for reviews see Kawabata et al., 1998; Massague et al., 2005; Nohe et al., 2004). This complex, in co-operation with a range of co-activators and corepressors, can affect the transcription of a wide variety of genes (for reviews see Attisano \& Wrana, 2000; Miyazono et al., 2001; Shi \& Massague, 2003). The I-Smads compete with the RSmads for binding to the type I receptor, and can also bind to Smad-4 to form a complex which is non-functional and which blocks the activated R-Smads from binding to Smad-4 to affect transcription.

BMPs have recently been found to also act via Smad-independent mechanisms, which do not involve transcriptional changes. These pathways are activated by the same receptors as those used in Smad-dependent signalling, but involve the stimulation of various intracellular signalling cascades, involving proteins such as ERK, PI3K, PKA, PKC, p38 mitogen activated protein (MAP) kinase, C-jun N-terminal kinase and nuclear factor kappa B. Many of these 
pathways are initiated by interaction of the BMP receptor with bone morphogenetic receptor associated molecule 1 (BRAM1) or with X-linked inhibitor of apoptosis (XIAP), stimulating the activation of TGF $\beta$-activated kinase 1 (TAK1) and TAK1-binding protein (TAB1) (for reviews see de Caestecker, 2004; Sieber et al., 2009). The MAP kinases enter the nucleus upon phosphorylation and affect transcription of target genes. BMP receptors are thought to act in such a transcription-independent manner to induce cytoskeletal changes, which may be involved in neural cell migration during development (see Sieber et al., 2009).

The physiological regulation of BMP signalling through their receptors is complex and involves a large array of modulatory molecules. For example, BMP signalling is modulated by the presence of several endogenous antagonists, which block or diminish the binding of BMPs to their specific receptors (for reviews, see Bragdon et al., 2011; de Caestecker, 2004; Kawabata et al., 1998; Rider \& Mulloy, 2011; Sieber et al., 2009). At least fifteen BMP antagonist molecules have been identified, some of which also act as antagonists of other TGF $\beta$ superfamily members. Noggin is the most-studied BMP antagonist and it has been shown to block the actions of BMP2, BMP4, BMP7, GDF5 and GDF6. Furthermore, several BMP co-receptors have been identified, which can either promote or inhibit BMP signalling (for reviews, see Corradini et al., 2009; Sieber et al., 2009). The repulsive guidance molecules (RGM)-a and -c, Dragon (RGMb) and the receptor tyrosine kinase (RTK) c-Kit are examples of positive co-receptors which augment signalling by BMPs, whereas the decoy receptor, $\mathrm{BMP}$ and activin membrane-bound protein (BAMBI), and the RTKs Ror2 and TrkC are negative modulators. Intracellular modulation of BMP signalling also occurs, whereby several proteins can act to regulate BMP signalling by binding to the intracellular region of their receptors and forming mulicomponent signalling complexes which can enhance or inhibit both Smad-dependent and Smad-independent pathways (for review, see Sieber et al., 2009). Ligand-dependent endocytic trafficking of the BMP receptors also plays a modulatory role, and can both enhance or decrease the efficiency of BMP signalling (for review, see de Caestecker, 2004). Individual BMPs can activate multiple signalling pathways by signalling through distinct receptor oligomeric complexes, demonstrating the complexity and diversity of the biological actions of these proteins.

\subsubsection{Effects of GDF5 in vitro}

On embryonic rat dopaminergic neurones in vitro, GDF5 has selective trophic actions which are comparable to those of GDNF. Application of GDF5 promotes the survival of dopaminergic neurones in embryonic rat midbrain cultures and protects them against the dopaminergic neurotoxin MPP+ (Krieglstein et al., 1995) and against free radical-induced damage (Lingor et al., 1999). Another study found that application of recombinant human GDF5 induced a dramatic increase in the number of dopaminergic neurones, in cultures of embryonic rat midbrain (O'Keeffe et al., 2004). This study found that the effects of GDF5 in these cultures may be dependent on BMPR1b, since application of GDF5 at the time of plating, when BMPR1b is expressed, increases dopaminergic neuronal number, but application after six days in vitro, when this receptor is no longer expressed, had no effect. GDF5 treatment also induced morphological changes in cultured embryonic rat dopaminergic neurones, stimulating neurite outgrowth and branching (Clayton \& Sullivan, 2007; O'Keeffe et al., 2004). Clayton and Sullivan found that the effects of GDF5 were much greater when cultures were prepared from the lateral part of the developing midbrain. Furthermore, the BMPR1b receptor was expressed at higher levels in the lateral than in the medial region, suggesting that GDF5 acts through this receptor to increase dopaminergic 
neuronal number. Combined application of GDF5 and GDNF have been shown to have additive neurotrophic effects on cultured embryonic rat dopaminergic neurones, indicating that these two factors may act on separate subpopulations of cells (Wood et al., 2005).

\subsection{MANF and CDNF}

MANF and CDNF are members of a recently-described family of evolutionarily-conserved proteins, of approximately 150-160 amino acids, which are secreted from glial cells and have potent effects on dopaminergic neurones (for review, see Lindholm \& Saarma, 2010). CDNF mRNA and protein have been found in both developing (E13 to postnatal day 10) and adult mouse striatum and substantia nigra, suggesting that this factor may provide trophic support to mature dopaminergic neuronal cell bodies and their terminals, as well play a role in the development of these cells (Lindholm et al., 2007). CDNF is a paralogue of MANF, which was originally isolated from a rat mesencephalic astrocyte cell line and found to have selective trophic effects on dopaminergic neurones in vitro (Petrova et al., 2003). Polymorphisms of CDNF have recently been linked to an early-onset form of PD (Choi et al., 2011). In vivo secretion of MANF has been demonstrated (Apostolou et al., 2008). Like CDNF, MANF is expressed in the rodent nigrostriatal system during the early postnatal period, as well as in the adult (Lindholm et al., 2008). The Drosophila homologue of MANF, DmMANF, is essential for the maintenance and function of dopaminergic neurones (Palgi et al., 2009). Although the receptors for MANF and CDNF have yet to be identified, it appears that they may act by a different mechanism to the GFL family members to exert their neurotrophic effects on dopaminergic neurones. It is possible that at least part of the action of MANF is via inhibition of endoplasmic reticulum (ER) stress-induced neuronal cell death (see Lindholm \& Saarma, 2010; Voutilainen et al., 2009), as MANF is located in the ER and has been shown to inhibit ER stress-induced non-neuronal cell death in vitro (Apostolou et al., 2008). MANF has also been found to have protective effects on cardiac myocytes in an in vitro model of ischemia (Tadimalla et al., 2008). Overexpression of MANF has recently been shown to block apoptotic cell death in sympathetic neurones cultured from the neonatal mouse superior cervical ganglion (Hellman et al., 2011), supporting an intracellular mechanism of action.

\section{Dopaminergic neurotrophic factors in animal models of PD}

\subsection{Effects of GDNF in vivo}

In normal adult rats, a single injection of GDNF into either the substantia nigra or striatum significantly increased the levels of dopamine and its metabolites in the striatum and nigra (Martin et al., 1996). Several studies have reported neuroprotective and functional (improvement of motor symptoms) effects of GDNF in adult animal models of PD (for reviews, see Balemans \& Van Hul, 2002; Bjorklund et al., 2009; Bjorklund \& Lindvall, 2000; Bjorklund et al., 1997; Deierborg et al., 2008; Gash et al., 1996; Ramaswamy et al., 2009). In one early study, repeated injections of recombinant rat GDNF protected against dopaminergic cell loss induced by transection of the adult rat medial forebrain bundle (MFB), the fibre bundle containing the dopaminergic projections from the substantia nigra to the striatum (Beck et al., 1995). Another study found that delivery of GDNF using polymer-encapsulated baby hamster kidney (BHK) cells at one week before axotomy of the adult rat MFB induced motor improvements and rescued nigral dopaminergic neurones, without significant protection of striatal dopamine levels (Tseng et al., 1997). 
The most widely-used laboratory model of PD involves unilateral injection of the selective dopaminergic toxin, 6-OHDA, into either the MFB, the substantia nigra or the striatum of the adult rat. This results in the degeneration of nigrostriatal dopaminergic neurones and consequent depletion of striatal dopamine transmission on one side of the brain. Stereotaxic injection of 6-OHDA into the MFB or substantia nigra induces a substantial lesion of the nigrostriatal pathway (Ungerstedt \& Arbuthnott, 1970), while intrastriatal injection of this toxin induces a more protracted neurodegeneration, which begins after a delay of about a week and continues for several weeks (Sauer \& Oertel, 1994). Several groups have examined the effects of intracerebral injection of recombinant GDNF in rats with 6-OHDA-induced lesions of the MFB. A single dose of GDNF to the substantia nigra, given four weeks after a 6-OHDA lesion of MFB, resulted in improvements in motor deficits (drug-induced rotational asymmetry, a commonly-used motor test in rat PD models) and preservation of nigral dopaminergic neurones (Bowenkamp et al., 1995; Hoffer et al., 1994). GDNF injection just above the substantia nigra and into the lateral ventricle immediately before 6-OHDA injection into the MFB conferred significant protective effects on nigral dopaminergic neurones, on striatal dopamine release and uptake, and on motor function (Opacka-Juffry et al., 1995). In adult rats with bilateral 6-OHDA lesions of the MFB, a model of severe PD, injection of high doses of GDNF into the lateral ventricles resulted in improved motor function and sparing of nigral dopaminergic neurones (Bowenkamp et al., 1997). Although GDNF has been reported to have protective actions in 6-OHDA-lesioned rats of all ages, its effects appear to be dependent on the age of the host, as one study found that young rats displayed significantly higher levels of neuroprotection than aged rats (Fox et al., 2001). This may be relevant to clinical trials, where the age of the patient may determine the extent of neuroprotection that is achievable with GDNF treatment.

The intrastriatal lesion model has been used extensively in studies on neurotrophic factors, since in this model it is possible to administer the factors while the progressive neurodegeneration is still taking place. Supranigral administration of recombinant human GDNF for four weeks, starting at the day of a 6-OHDA-induced lesion of the rat striatum, completely prevented nigral cell death (Sauer et al., 1995). When administered one day before a 6-OHDA lesion of either the striatum or substantia nigra, intranigral injection of GDNF had protective effects on rat nigral dopaminergic cell bodies (Kearns \& Gash, 1995). A series of four intrastriatal injections of GDNF was found to decrease drug-induced rotations and preserve nigrostriatal dopaminergic neurones in adult rats with 6-OHDAinduced striatal lesions (Shults et al., 1996). Long-term rescue of nigrostriatal dopaminergic neurones from intrastriatal 6-OHDA lesions was reported after short-term GDNF treatment, beginning five days after the lesion and being administered every fourth day for one month (Winkler et al., 1996). Long-term protection against rotational asymmetry, reductions in striatal dopamine levels and uptake, and death of nigral dopaminergic cell bodies induced by 6-OHDA lesions of the MFB was conferred by a single dose of GDNF, divided between the lateral ventricle and substantia nigra (Sullivan et al., 1998). GDNF injections into the striatum at one week after an intrastriatal 6-OHDA lesion resulted in reinnervation of the striatum as well as recovery of motor function (Rosenblad et al., 1998), indicating that the ability of intrastriatal GDNF injection to confer behavioural improvements may be due to its effects on the remaining striatal afferents in the partially-denervated striatum.

For application to clinical studies, the optimal injection site for production of safe and effective results is obviously an important consideration. Some studies have directly compared the sites of administration of GDNF in 6-OHDA-lesioned rats. In a study 
designed to compare the various sites of intracerebral injection, intrastriatal GDNF had significant protective effects on motor function and on the integrity of the nigrostriatal pathway, intranigral GDNF protected nigral cell bodies but not striatal innervation or motor function, while intraventricular GDNF had no significant effects (Kirik et al., 2000). Another study by the same group found that delayed intraventricular infusion of GDNF starting two weeks after an intrastriatal 6-OHDA lesion had profound protective effects on the integrity and function of the nigrostriatal pathway, which lasted for six weeks after cessation of GDNF infusion, whereas the effects of intrastriatal infusion stopped upon withdrawal of GDNF (Kirik et al., 2001). Another group found that delayed intrastriatal infusion of a high dose of GDNF at four weeks after an intrastriatal 6-OHDA lesion induced restorative effects on the nigrostriatal dopaminergic pathway, in terms of both motor behaviour and the integrity of dopaminergic neurones and their terminals (Aoi et al., 2000). Thus, the intrastriatal route of administration appears to be the most efficacious in this rodent model of PD. In another study, sequential application of GDNF over the nigra for two weeks, followed by injections of GDNF into the striatum for three weeks, in rats with intrastriatal 6OHDA lesions, protected nigral dopaminergic cell bodies but did not prevent striatal denervation or improve motor function (Rosenblad et al., 2000). This suggests that the motor improvements observed in the other studies were dependent on an ability of GDNF to induce reinnervation of the lesioned striatum, perhaps by stimulating axonal sprouting from the remaining dopaminergic neurones. Thus, once the axonal retraction to the level of the nigra has occurred, application of GDNF to the striatum appears to be ineffective. This is an important consideration for clinical studies, as it suggests that there is a window of opportunity in which GDNF application may be therapeutically effective, but that this factor may not be useful at advanced stages of the disease.

In another commonly-used animal model of PD, N-methyl-4-phenyl-1,2,3,6tetrahydropyridine (MPTP)-treated adult mice, GDNF administration induces potent effects on nigrostriatal dopaminergic neurones (Tomac et al., 1995). This study found that GDNF could be injected either before or one week after MPTP treatment, to confer significant preventative or restorative effects, respectively. Another study reported that GDNF injection into the striatum at one week after MPTP treatment of young or aged mice induced recovery of motor function (Date et al., 1998).

Another well-established animal model of PD is the MPTP-treated non-human primate brain, which has the advantage of being closer than the rodent brain to the human brain in terms of organisation and size. Gash and colleagues showed that administration of recombinant GDNF every four weeks in MPTP-treated rhesus monkeys induced motor recovery as well as a significant increase in the size of cell nigral dopaminergic neurones and in the density of their striatal projections (Gash et al., 1996). Combined application of oral levodopa and intracerebroventricular GDNF resulted in significant behavioural improvements with reduced levodopa-induced side-effects, in MPTP-treated rhesus monkeys (Miyoshi et al., 1997). Another study found that intraventricular GDNF improved motor function and reduced levodopa-induced dyskinesias in MPTP-treated monkeys (Iravani et al., 2001). Significant recovery of motor function for at least four months was reported in MPTP-treated monkeys that had received GDNF into the lateral ventricles (Zhang et al., 1997). Intraventricular injections of GDNF were found to induce increases in dopamine levels in the substantia nigra, but not the striatum, of MPTP-treated rhesus monkeys (Gerhardt et al., 1999). Infusion of GDNF into the putamen of MPTP-treated rhesus monkeys induced a gradual and significant reduction in parkinsonian symptoms (Grondin 
et al., 2002). This appeared to be a regenerative action, since GDNF was injected at three months after the MPTP lesion, when the nigrostriatal pathway had presumably undergone significant degeneration. Chronic intraputaminal administration of GDNF in aged rhesus monkeys had a long-lasting protective action on nigrostriatal dopaminergic neurones and on motor function, without any adverse side-effects (Maswood et al., 2002). In addition to effects on PD models, a single intranigral injection of GDNF can induce increases in nigrostriatal dopamine neurotransmission in normal rhesus monkeys, lasting for at least three weeks (Gash et al., 1995).

Like all neurotrophic proteins, GDNF is metabolised rapidly in the brain and thus single injections of this factor cannot confer permanent effects. Gene therapy approaches have been applied in attempts to achieve long-term and targeted delivery of GDNF to the injured nigrostriatal pathway. An adenoviral vector was used to deliver GDNF into or close to the substantia nigra (Choi-Lundberg et al., 1997; Mandel et al., 1997) or into the striatum (Balemans \& Van Hul, 2002; Bilang-Bleuel et al., 1997; Choi-Lundberg et al., 1998) of rats with intrastriatal 6-OHDA lesions. Each of these studies reported significant motor improvements, as well as direct effects on nigral dopaminergic neurones and their terminals. When administered into the substantia nigra at ten weeks after a 6-OHDA lesion of the adult rat MFB, adenoviral vector-delivered GDNF induced significant motor improvements and recovery of nigrostriatal dopamine neuronal function (Lapchak et al., 1997). Adenoviral-delivered GDNF induced behavioural and neuroprotective effects when injected into the substantia nigra, but not when injected intrastriatally, in rats that had intrastriatal 6-OHDA lesions (Kozlowski et al., 2000). In MPTP-treated mice, adenoviral vector-mediated GDNF delivery to the striatum prevented depletion of striatal dopamine levels (Kojima et al., 1997). A study which compared the effects of intrastriatal and perinigral injection of an adenoviral vector encoding GDNF found that, while both injection routes conferred protective effects on dopaminergic cell bodies in the nigra, only the intrastriatal route reduced motor deficits in rats with intrastriatal 6-OHDA lesions (Connor et al., 1999).

Another vector system, based on adeno-associated virus (AAV) 2, has also shown efficacy in animal models of PD. Mandel and co-workers reported significant protective effects on the nigrostriatal pathway and its functioning, in adult rats with intrastriatal 6-OHDA lesions following intranigral injection of AAV2-GDNF either three weeks before (Mandel et al., 1997) or just after the lesion (Mandel et al., 1999). AAV2-mediated delivery of GDNF to the striatum, but not to the substantia nigra, induced gradual behavioural recovery and regeneration of the 6-OHDA-lesioned nigrostriatal system in adult rats (Kirik et al., 2000). AAV vectors have advantages over adenoviral vectors in that they can integrate and stably express their transgene product in non-dividing cells such as neurons. Also, they are relatively safe as there is little or no host immune response, due to the absence of viral genes in these vectors. Their disadvantage is that they can only deliver gene constructs of relatively small size compared to those that adenoviral vectors can accommodate. Furthermore, there is a delay before the transgene is expressed following intracerebral injection of an AAV vector.

A third type of vector system, based on lentiviruses, has also been used to deliver GDNF in PD animal models, with promising results. Lentiviral vectors have the capacity to deliver large transgenes and they can integrate efficiently into non-dividing cells. Delivery of the human GDNF gene using lentiviral vectors in MPTP-lesioned rhesus monkeys and in aged rhesus monkeys achieved long-term gene expression and significant functional benefits 
(Kordower et al., 2000). Kordower and colleagues administered lentiviral-GDNF to the striatum and substantia nigra of nonlesioned aged monkeys and MPTP-treated young monkeys and found extensive expression of GDNF in all of the brains. Lentiviral-delivered GDNF reversed motor deficits in the aged monkeys, and prevented nigrostriatal degeneration and the development of functional deficits in the MPTP-lesioned animals. Another study used a lentiviral vector to achieve long-term delivery of GDNF to the striatum and substantia nigra of aged rhesus monkeys, and found that this treatment conferred significant protective effects on the functioning and integrity of the nigrostriatal pathway (Emborg et al., 2009). Lentiviral delivery of GDNF was also found to increase the number of intrinsic dopaminergic neurones in the primate striatum (Palfi et al., 2002). Dowd et al found that lentiviral-mediated GDNF delivery into the striatum and above the substantia nigra rescued complex motor behaviour (such as corridor, staircase, stepping and cylinder tasks), as well as drug-induced rotational asymmetry, in rats with 6-OHDA lesions of the MFB (Dowd et al., 2005). Lentiviral-mediated delivery is very effective, but there are concerns about its safety, which will have to be addressed before clinical application of this system is feasible.

Thus, gene therapy has shown great promise as a means of achieving long-term and targeted delivery of GDNF to the nigrostriatal system (for reviews see Bjorklund \& Lindvall, 2000; Kordower, 2003; Manfredsson et al., 2009). Viral vector technology has also been used to deliver GDNF to the brain in models of other diseases. For example, significant neuroprotective effects were reported in a study that used adenoviral vectors to deliver GDNF to the cortex in an adult rat model of focal cortical trauma (Hermann et al., 2001). Adenoviral-mediated GDNF expression has been reported to rescue rat retinal ganglion cells after axotomy (Schmeer et al., 2002), to protect motoneurones in a transgenic mouse model of amyotrophic lateral sclerosis (Wang, et al., 2002) and to promote functional recovery in a rat model of spinal cord injury (Tai et al., 2003). AAV-2-mediated delivery of GDNF was found to confer neuroprotective effects and motor improvements in both a toxinmediated adult rat model (McBride et al., 2003) and in a transgenic mouse model of Huntington's disease (McBride et al., 2006).

Another avenue of exploration is the co-administration of neurotrophic factors with neuronal transplants in cell replacement therapy approaches to PD. Transplantation of embryonic midbrain tissue is a promising and successful therapy for PD, but is limited by the poor survival of the transplanted dopaminergic neurones (for recent reviews, see Brundin et al., 2010; Hedlund \& Perlmann, 2009; Olanow et al., 2009). GDNF has been shown by several groups to improve the survival and integration of grafted embryonic dopaminergic neurones in animal models of PD. Rosenblad and colleagues reported that repeated injections of this factor adjacent to embryonic rat ventral midbrain grafts in the 6OHDA-lesioned rat striatum improved the survival of the grafted dopaminergic cells and induced earlier recovery of motor function than untreated grafts (Rosenblad et al., 1996). Improvements in the survival of grafted dopaminergic neurones and their integration into the host striatum were also reported after pre-incubation of the grafts with GDNF (Apostolides et al., 1998; Granholm et al., 1997; Sullivan et al., 1998; Yurek, 1998). Injection of GDNF along the nigrostriatal tract stimulated the outgrowth of dopaminergic fibres from intranigral grafts towards the striatum (Sinclair et al., 1996; Tang et al., 1998; Wang, Y. et al., 1996). Enhancement of complex motor functions, as well as improved graft survival, were found in 6-OHDA-lesioned rats that had received GDNF-pretreated grafts (Mehta et al., 1998). GDNF pretreatment has also been used to promote the survival of human fetal 
midbrain tissue, prior to grafting into two PD patients (Mendez et al., 2000). These patients displayed a large increase in fluorodopa uptake after one year, an index of striatal dopaminergic transmission, as measured by positron emission tomography (PET).

Ex vivo gene therapy approaches have been applied in attempts to extend the effects of exogenous GDNF, which is rapidly metabolised in vivo. Genetically-modified embryonic rat midbrain cells which overexpress GDNF have been found to induce earlier functional recovery in 6-OHDA-lesioned rats than control grafts (Bauer et al., 2000). GDNFoverexpressing rat neural precursor cells also significantly increased the survival of cografted embryonic dopaminergic neurones (Ostenfeld et al., 2002). Human neural progenitor cells have been used to deliver GDNF, which conferred protective effects on the lesioned nigrostriatal pathway in adult rats (Behrstock et al., 2006). This cellular delivery system, which allows the release of GDNF under an inducible promoter, has also been found to provide GDNF to the aged monkey brain for at least three months (Behrstock et al., 2006). Encapsulation technology involves enclosing cells within a semi-permeable membrane composed of polymer fibres, which allows outward diffusion of any proteins secreted by the cells, while preventing the cells from proliferating extensively and forming tumours. Intrastriatal grafting of an encapsulated GDNF-expressing human (BHK) cell line has been shown to confer neuroprotective and restorative effects in 6-OHDA-lesioned rats (Date et al., 2001; Shingo et al., 2002), particularly when the GDNF-expressing cells are implanted at an early stage of the disease progression (Yasuhara et al., 2005). Encapsulated human fibroblasts genetically engineered to overexpress GDNF were found to exert regenerative effects when implanted into the rat striatum one week after an intrastriatal 6OHDA lesion (Sajadi et al., 2006). Although the cells were removed after six weeks, the regenerative effects on motor function and on nigral dopaminergic neurones were evident for a further seven weeks, indicating that transient delivery of GDNF was sufficient to confer sustained effects. In MPTP-treated primates, encapsulated GDNF-expressing cells induced transient motor improvements and increases in striatal dopamine uptake, without any adverse side-effects (Kishima et al., 2004). Encapsulated cells expressing GDNF have also been applied in combination with embryonic rat brain grafts in 6-OHDA-lesioned rats, and were found to improve the survival of the grafted dopaminergic neurones and their functional effects (Sautter et al., 1998). Encapsulated cell technology may have great potential for future clinical studies, should the promising effects found in these animal studies be extended to show long-term and safe delivery of appropriate doses of neurotrophic proteins (for reviews see Bensadoun et al., 2003; Lindvall \& Wahlberg, 2008).

\subsection{Effects of neurturin in vivo}

Neurturin has been found to exert protective and functional effects on dopaminergic nigrostriatal neurones after 6-OHDA lesions of the adult rat MFB (Akerud et al., 1999; Horger et al., 1998) or of the striatum (Oiwa et al., 2002; Rosenblad et al., 1999), and after axotomy of the MFB in adult rats (Tseng et al., 1998). The study by Rosenblad and colleagues directly compared the effects of neurturin with those of GDNF in the striatal 6OHDA lesion model. They found that neurturin was less efficacious than GDNF after intrastriatal and especially after intraventricular delivery, which may reflect poor solubility of neurturin in vivo (Rosenblad et al., 1999). Another study showed that delivery of neurturin into the cerebral ventricles of adult rats using mini-pumps resulted in an increase in striatal dopamine levels (Hoane et al., 1999). A recent study reported that intranigral injection of recombinant neurturin induced increases in striatal dopamine release, which 
were similar in magnitude to those induced by intranigral injection of recombinant GDNF (Cass \& Peters, 2010). Intracerebral delivery of recombinant neurturin has also been found to protect nigrostriatal dopaminergic neurones and induce improvements in motor function in MPTP-treated monkeys (Grondin et al., 2008; Li et al., 2003). Co-administration with recombinant neurturin protein has been reported to improve the survival of fetal rat dopaminergic neurones after intrastriatal grafting into 6-OHDA-lesioned adult rats (Rosenblad et al., 1999).

The need for sustained delivery of neurotrophic proteins to the brain led to studies using viral vector-based delivery systems, which have shown promising results in animal models of PD. Lentiviral gene delivery to the striatum of 6-OHDA-lesioned adult rats of a modified neurturin construct, which had the pro-region deleted and replaced with an immunoglobulin heavy-chain signal peptide, had protective effects on the nigrostriatal pathway (Fjord-Larsen et al., 2005). Sustained functional recovery, with minimal sideeffects, was achieved following stereotaxic injection of an adeno-associated virus (AAV) 2based vector encoding the human neurturin gene, in MPTP-treated monkeys (Kordower et al., 2006) and 6-OHDA-lesioned rats (Gasmi et al., 2007). Stable expression of neurturin using this AAV2 delivery system was achieved for at least a year in rats (Gasmi et al., 2007). Kordower and colleagues showed that, ten months after treatment with AAV2-neurturin into the striatum and substantia nigra, MPTP-treated parkinsonian monkeys showed a large reduction in the intensity of their motor symptoms compared to buffer-injected animals, which displayed stable symptoms throughout the study. This functional recovery was accompanied by significant preservation of dopaminergic neurones (Kordower et al., 2006). A study using the same expression system in 6-OHDA-lesioned adult rats found long-term neurturin expression in the striatum and dose-dependant protective effects on the nigrostriatal dopaminergic neurones for at least ten months (Gasmi et al., 2007). Similar results were found after application of this system in aged monkeys and no adverse effects were recorded in this study after thorough toxicological testing (Herzog et al., 2007). A further study by this group found that the expression of neurturin using this system could be sustained for a year in rhesus monkeys, as could its therapeutic effects (Herzog et al., 2009). Unlike the case with GDNF, no antibodies to neurturin or no pathological abnormalities were detected after AAV2-delivery in primates (see Bartus et al., 2007).

Neurturin has also been reported to have protective effects on striatal projection neurones in a rat model of Huntington's disease (Perez-Navarro et al., 2000). AAV-2-mediated delivery of neurturin had neuroprotective effects and induced motor improvements in a genetic mouse model of Huntington's disease (Ramaswamy et al., 2009).

\subsection{Effects of GDF5 in vivo}

Several in vivo studies have shown that GDF5 can protect and restore adult rat nigrostriatal dopaminergic neurones in 6-OHDA-lesioned models of PD. The first such study reported that intracerebral injection of recombinant human GDF5 just above the substantia nigra and into the lateral ventricles produced significant improvements in motor function, protected nigral dopaminergic neurones and their striatal terminals, and preserved striatal levels of dopamine, its metabolites and its uptake, in rats with 6-OHDA lesions of the MFB (Sullivan et al., 1997). A follow-up study compared three injection sites and found that application of GDF5 into either the striatum or substantia nigra, but not into the lateral ventricle, produced optimal neuroprotective effects (Sullivan et al., 1999). Delayed intrastriatal administration of recombinant human GDF5 at one or two weeks after an intrastriatal 6-OHDA lesion resulted 
in significant improvements in motor behaviour but only the one-week injection regimen induced sparing of nigral dopaminergic cell bodies, whereas there was no significant rescue of striatal dopaminergic terminals after either time-point of treatment (Hurley et al., 2004). This indicates that there is a window of time at which the degenerating nigrostriatal pathway can be rescued by exogenous trophic factors. This has relevance to clinical studies, as such therapies may only be effective at earlier stages of the disease. GDF5 has also been reported to improve the survival and function of grafted dopaminergic neurones to the same extent as GDNF (Sullivan et al., 1998). This study found that incubation of embryonic rat midbrain tissue in GDF5 or GDNF prior to intrastriatal grafting into rats which had 6OHDA lesions of the MFB, produced significant improvements in the survival of the grafted cells. Furthermore, GDF5-treated grafts conferred significant motor improvements and preservation of nigral dopaminergic neurones and their striatal terminals in 6-OHDAlesioned rats, to at least the same extent as GDNF-treated grafts (Sullivan et al., 1998). Each of these in vivo studies involved infusion of recombinant GDF5 protein, which can only be effective for a limited time due to its being metabolised in the brain. Future studies will examine alternative administration methods, such as viral vector-mediated delivery or the use of encapsulated cell technology. One recent study reported that GDF5-overexpressing embryonic rat midbrain transplants survived well in the 6-OHDA-lesioned adult rat striatum and had significant effects to improve motor behaviour in these animals (O'Sullivan et al., 2010).

\subsection{Effects of MANF / CDNF in vivo}

Intracerebral injection of recombinant human CDNF has been reported to have potent protective and restorative effects on the 6-OHDA-lesioned adult rat nigrostriatal pathway (Lindholm et al., 2007). Intrastriatal administration of recombinant human MANF also has protective and restorative effects on dopaminergic neurones in 6-OHDA-lesioned adult rats (Voutilainen et al., 2009). Both of these studies reported motor recovery (reductions in druginduced rotations) and preservation of dopaminergic nigral cell bodies and their terminals in the striatum, conferred by intrastriatal injection of the neurotrophic factor six hours before or four weeks after intrastriatal injection of 6-OHDA. The same group recently reported that intrastriatal infusion of CDNF via mini-pumps for two weeks, beginning at two weeks after an intrastriatal 6-OHDA lesion, was able to confer motor improvements and partially protect dopaminergic nigral cell bodies and their striatal terminals (Voutilainen et al., 2011). It is interesting that MANF appears to be transported through the brain in a different manner to that of GDNF, as radiolabelled MANF is transported to the cortex after intrastriatal injection (Voutilainen et al., 2009), while labelled GDNF is retrogradely transported to the substantia nigra (Leitner et al., 1999; Tomac et al., 1995), as is labelled CDNF (Voutilainen et al., 2011). Recombinant human MANF has also been reported to have neuroprotective effects on cortical neurones in an adult rat model of ischemic stroke (Airavaara et al., 2009).

\section{Dopaminergic neurotrophic factors in clinical trials}

\subsection{GDNF in clinical trials}

The potent and reproducible effects of GDNF in animal models led to the initiation of clinical trials using this factor in PD patients. The clinical application of neurotrophic factors is hampered by the fact that these proteins do not cross the blood-brain barrier, and are 
rapidly degraded in vivo. The need for direct intracerebral delivery of neurotrophic factors may increase the level of complications in patients. The first clinical trial in PD patients was a randomised controlled trial involving 50 patients, and used intraventricular delivery of recombinant human GDNF (r-methionylGDNF, liatermin ${ }^{\circledR}$, manufactured by Amgen) or placebo (Nutt et al., 2003). This study reported no significant benefits of GDNF treatment over the placebo, probably because GDNF did not reach the striatum in sufficient amounts. In addition, troublesome side-effects were observed, including pain, depression, appetite loss and l'Hermitte's sign (Kordower et al., 1999; Nutt et al., 2003); these may have been due to the intraventricular delivery mechanism that was used in this trial.

Due to the suggestion that intraventricular delivery did not achieve GDNF delivery to the target tissues in the striatum, subsequent trials used direct administration to brain parenchyma using a catheter system. Promising results emerged from two open-label trials, which used intraputaminal infusion of recombinant GDNF (Gill et al., 2003; Love et al., 2005; Patel et al., 2005; Slevin et al., 2005). These trials both reported improvements in the patients' motor symptoms and in activities of daily living, without any serious side-effects. Gill and colleagues demonstrated that direct unilateral (in one patient) or bilateral (in four patients) intraputaminal infusion of GDNF had long-lasting benefits in five patients suffering from advanced PD. After 24 months of treatment, all patients reported complete absence of akinesia and a $73 \%$ reduction in the duration of dyskinesic episodes. Motor dysfunction was reduced in both on- and off- medication phases compared to the pre-treatment level (UPDRS part III score was reported to be $57 \%$ lower off medication and $48 \%$ lower on medication). Similarly, functional deficits were reduced by $63 \%$ when off medication and $58 \%$ when on medication (UPDRS part II score) (Patel et al., 2005). The second study, by Slevin and co-workers, used unilateral intraputaminal infusion of escalating doses of GDNF in ten patients with advanced PD and reported similar results, showing bilateral motor improvements after 24 weeks (Slevin et al., 2005). In both studies, the only consistent adverse effect was a mild l'Hermitte's sign. Improvements in dopamine storage were detected in the regions surrounding the catheter which was used for infusion of GDNF (Gill et al., 2003; Love et al., 2005).

The two open-label studies demonstrated the feasibility and sustainability of GDNF treatment by intraputaminal infusion. However, a subsequent randomised placebocontrolled trial, involving 34 patients (17 received GDNF and 17 received placebo), reported no significant motor improvements in PD patients (Lang et al., 2006). After six months of bilateral intraputaminal infusion of recombinant GDNF, there were no significant differences between the motor UPDRS scores in patients that had received GDNF and in those that had received a placebo. Furthermore, safety concerns were raised, since approximately $10 \%$ of the GDNF-treated patients developed antibodies against the peptide, which could potentially counteract the therapeutic benefits (Tatarewicz et al., 2007). A similar proportion of patients who had participated in the two open-label trials also developed antibodies to GDNF (Slevin et al., 2005). PET studies showed a significant increase in 18F-dopa intake in the GDNF-infused patients compared to the placebo group, demonstrating a functional effect of GDNF infusion, although this did not translate into significant motor improvements (Lang et al., 2006). The discrepancies between the openlabel and placebo-controlled trials may have been due to variations in patient selection, as well as to a placebo effect. Optimisation of surgical methodologies, catheter design and positioning, drug dosage and diffusion, and patient selection will be necessary for any future GDNF clinical studies. The development of inexplicable cerebellar pathology in a 
primate model of PD after administration of a high dose of GDNF has raised a further safety issue (Hovland et al., 2007). This resulted in a controversial decision by Amgen to cease all clinical trials using GDNF (see Barker, 2006; Lang et al., 2006; Penn et al., 2006). A recent study paved the way for future clinical trials by investigating GDNF distribution in the non-human primate brain following AAV2-mediated intraputaminal delivery (Richardson et al., 2011). It appears to be generally accepted that GDNF therapy for PD requires further development in pre-clinical trials and it is probable that alternative methodologies, such as viral vectormediated expression, may prove to be more effective for achieving long-term and targeted GDNF delivery (see Evans \& Barker, 2008; Morrison et al., 2007; Sherer et al., 2006).

\subsection{Neurturin in clinical trials}

Based on the promising results found in animal studies using AAV2-mediated gene transfer of neurturin (CERE-120®), an open-label Phase 1 clinical trial using gene therapy to deliver neurturin was initiated in PD patients by the company Ceregene (Marks et al., 2008). Twelve patients, each suffering from advanced PD, received bilateral intraputaminal injections of AAV2-neurturin (at one of two doses) and were followed for twelve months. Results showed that neurturin-treated patients displayed reductions in their off-medication UPDRS score, decreases in the time spent in the 'off' period and reductions in dyskinesias, without any adverse side-effects (Marks et al., 2008). However, a subsequent double-blind Phase 2 trial, which involved 58 PD patients, was reported to have failed. In this trial, intraputaminal AAV2-neurturin did not have superior effects on motor function than sham surgery, when assessed after twelve months, and only modest benefits were recorded after eighteen months. Serious adverse side-effects were reported in about a third of the neurturin-treated patients (Marks et al., 2010). Ceregene began to recruit PD patients for a new double-blind trial using AAV2-neurturin in September 2010 (www.ceregene.com/ press_101910.asp). This multi-centre phase 2 trial will involve about 52 patients, half of whom will receive intraputaminal AAV2-neurturin and half of whom will receive sham

\begin{tabular}{|c|c|c|c|c|c|c|c|}
\hline $\begin{array}{l}\text { Neurotrophic } \\
\text { factor }\end{array}$ & Trial type & $\begin{array}{l}\text { Delivery } \\
\text { Site }\end{array}$ & $\begin{array}{c}\text { No. of } \\
\text { patients }\end{array}$ & $\begin{array}{l}\text { Age / duration of } \\
\text { disease (years) }\end{array}$ & Benefits & Side-effects & Reference \\
\hline $\begin{array}{c}\text { rh-methionyl- } \\
\text { GDNF }\end{array}$ & $\begin{array}{c}\text { MC,R,DB, } \\
\text { PC }\end{array}$ & ICV & 50 & $58 \pm 8 / 11 \pm 6$ & No & $\begin{array}{c}\text { LS, } \\
\text { Nausea, } \\
\text { Anorexia }\end{array}$ & Nutt 2003 \\
\hline $\begin{array}{l}\text { rh-methionyl- } \\
\text { GDNF }\end{array}$ & $\begin{array}{l}\text { Open- } \\
\text { label }\end{array}$ & $\mathrm{IPu}$ & 5 & $54.2 \pm 6 / 19 \pm 9.8$ & Yes & LS & $\begin{array}{l}\text { Gill } 2003 \\
\text { Patel } 2005\end{array}$ \\
\hline $\begin{array}{l}\text { rh-methionyl- } \\
\text { GDNF }\end{array}$ & $\begin{array}{l}\text { Open- } \\
\text { label }\end{array}$ & $\mathrm{IPu}$ & 10 & $57.9 \pm 9.3 / 8.7 \pm 3.6$ & Yes & $\begin{array}{c}\text { LS, } \\
\text { Headaches }\end{array}$ & Slevin 2005 \\
\hline $\begin{array}{l}\text { rh-methionyl- } \\
\text { GDNF }\end{array}$ & $\begin{array}{c}\text { MC,R,DB, } \\
\text { PC }\end{array}$ & $\mathrm{IPu}$ & 33 & $56 \pm 7.2 / 9.7 \pm 3.9$ & No & $\begin{array}{c}\text { LS, } \\
\text { Anti-GDNF } \\
\text { antibodies }\end{array}$ & Lang 2006 \\
\hline $\begin{array}{c}\text { AAV2- } \\
\text { neurturin }\end{array}$ & $\begin{array}{l}\text { Open- } \\
\text { label }\end{array}$ & $\mathrm{IPu}$ & 12 & $57 \pm 8 / 11 \pm 3$ & Yes & Headaches & Marks 2008 \\
\hline $\begin{array}{c}\text { AAV2- } \\
\text { neurturin }\end{array}$ & $\begin{array}{l}\text { MC, DB, } \\
\text { SSC }\end{array}$ & $\mathrm{IPu}$ & 58 & $60 \pm 7 / 10 \pm 3$ & No & Headaches & Marks 2010 \\
\hline
\end{tabular}

(rh - recombinant human, MC - multi-centre, R - randomised, DB - double-blind,

PC - placebo-controlled, SSC - sham surgery-controlled, ICV - intracerebroventricular,

$\mathrm{IPu}$ - intraputaminal, LS - 1'Hermitte's sign)

Table 1. Clinical trials using neurotrophic factors 
surgery. It is hoped that a new dosing regimen, designed to maximise the delivery of the neurturin gene throughout the degenerating nigrostriatal system, will be the key to a promising outcome from this trial. This hypothesis is based on a post mortem analysis on the brains of some of the patients who had received AAV2-neurturin (and who had died of unrelated causes), which found that neurturin had been retrogradely transported from the intraputaminal injection site to the substantia nigra (Bartus et al., 2011). The company subsequently administered AAV2-neurturin to both the substantia nigra and the striatum of six PD patients and, based on analysis of the safety data from these six patients, are now recruiting patients for the second phase of this trial.

\section{Conclusion}

Despite the recent disappointing results in clinical trials with GDNF and neurturin, there remains an optimism that neurotrophic factors will prove to be useful in PD therapy (see Aron \& Klein, 2011; Deierborg et al., 2008; Manfredsson et al., 2009). Optimisation of delivery methods is needed and vital information is being gleaned in this respect from studies in animal models of PD, such as grafting of encapsulated cells expressing neurotrophic factors and viral-mediated neurotrophic factor delivery (for reviews see Bjorklund et al., 2000; Deierborg et al., 2008; Kordower, 2003; Zurn et al., 2001). It is likely that neurotrophic factors will be most applicable in the early stages of the disease, to provide neuroprotection to the remaining nigrostriatal dopaminergic neurones before extensive neuronal loss has occurred (see Bjorklund et al., 2009). For future clinical trials, optimisation of surgical and infusion protocols, as well as careful patient selection, will be critical to advance this promising therapeutic approach. Animal studies have provided signs that neurotrophic factor therapy may be more applicable in young patients than in old, and also that patients with an earlier, less severe, disease stage may be more responsive to this type of therapy than those at advanced disease stages.

Researchers are currently investigating the use of stem or progenitor cells as a possible alternative to freshly-dissected embryonic midbrain for transplantation in PD patients. The use of such cells would alleviate some of the ethical and practical concerns associated with the use of fresh embryonic tissue. It is likely that neurotrophic factors could be used to improve stem cell therapy for $\mathrm{PD}$, both to enhance the survival of transplanted dopaminergic precursor cells, and to induce a dopaminergic cell fate in unspecified progenitors.

In conclusion, much research still remains to be conducted in the area of neurotrophic factor therapy for PD. In the case of those factors which have been tested in clinical trials (GDNF and neurturin) optimisation of the surgical delivery procedures and patient selection will be critical to the ongoing development of this therapeutic approach. Exploration of novel delivery mechanisms, such as viral vector-mediated delivery (as has been used in the Ceregene neurturin trials) and cell encapsulation, which has been tested in animal models of PD to deliver GDNF, will be critical. More information is needed about factors such as GDF5 and CDNF, which have shown promise in preclinical models of PD. Knowledge of the receptors and signal transduction pathways that are involved in the neurotrophic and protective effects of these factors will aid the future development of safe and targeted therapeutics.

\section{References}

Airaksinen, M.S. \& Saarma, M. (2002). The GDNF family: signalling, biological functions and therapeutic value. Nat Rev Neurosci, Vol. 3, No. 5, pp. 383-394. 
Airaksinen, M.S.; Titievsky, A. \& Saarma, M. (1999). GDNF family neurotrophic factor signaling: four masters, one servant? Mol Cell Neurosci, Vol. 13, No. 5, pp. 313-325.

Airavaara, M.; Shen, H.; Kuo, C.C.; Peranen, J.; Saarma, M.; Hoffer, B. \& Wang, Y. (2009). Mesencephalic astrocyte-derived neurotrophic factor reduces ischemic brain injury and promotes behavioral recovery in rats. J Comp Neurol, Vol. 515, No. 1, pp. 116124.

Akerud, P.; Alberch, J.; Eketjall, S.; Wagner, J. \& Arenas, E. (1999). Differential effects of glial cell line-derived neurotrophic factor and neurturin on developing and adult substantia nigra dopaminergic neurons. J Neurochem, Vol. 73, No. 1, pp. 70-78.

Akerud, P.; Holm, P.C.; Castelo-Branco, G.; Sousa, K.; Rodriguez, F.J. \& Arenas, E. (2002). Persephin-overexpressing neural stem cells regulate the function of nigral dopaminergic neurons and prevent their degeneration in a model of Parkinson's disease. Mol Cell Neurosci, Vol. 21, No. 2, pp. 205-222.

Aoi, M.; Date, I.; Tomita, S. \& Ohmoto, T. (2000). The effect of intrastriatal single injection of GDNF on the nigrostriatal dopaminergic system in hemiparkinsonian rats: behavioral and histological studies using two different dosages. Neurosci Res, Vol. 36, No. 4, pp. 319-325.

Apostolides, C.; Sanford, E.; Hong, M. \& Mendez, I. (1998). Glial cell line-derived neurotrophic factor improves intrastriatal graft survival of stored dopaminergic cells. Neuroscience, Vol. 83, No. 2, pp. 363-372.

Apostolou, A.; Shen, Y.; Liang, Y.; Luo, J. \& Fang, S. (2008). Armet, a UPR-upregulated protein, inhibits cell proliferation and ER stress-induced cell death. Exp Cell Res, Vol. 314, No. 13, pp. 2454-2467.

Aron, L. \& Klein, R. (2011). Repairing the parkinsonian brain with neurotrophic factors. Trends Neurosci, Vol. 34, No. 2, pp. 88-100.

Attisano, L. \& Wrana, J.L. (2000). Smads as transcriptional co-modulators. Curr Opin Cell Biol, Vol. 12, No. 2, pp. 235-243.

Balemans, W. \& Van Hul, W. (2002). Extracellular regulation of BMP signaling in vertebrates: a cocktail of modulators. Dev Biol, Vol. 250, No. 2, pp. 231-250.

Baloh, R.H.; Enomoto, H.; Johnson, E.M., Jr. \& Milbrandt, J. (2000). The GDNF family ligands and receptors - implications for neural development. Curr Opin Neurobiol, Vol. 10, No. 1, pp. 103-110.

Baloh, R.H.; Tansey, M.G.; Lampe, P.A.; Fahrner, T.J.; Enomoto, H.; Simburger, K.S.; Leitner, M.L.; Araki, T.; Johnson, E.M., Jr. \& Milbrandt, J. (1998). Artemin, a novel member of the GDNF ligand family, supports peripheral and central neurons and signals through the GFRalpha3-RET receptor complex. Neuron, Vol. 21, No. 6, pp. 12911302.

Barker, R.A. (2006). Continuing trials of GDNF in Parkinson's disease. Lancet Neurol, Vol. 5, No. 4, pp. 285-286.

Barnett, M.W.; Fisher, C.E.; Perona-Wright, G. \& Davies, J.A. (2002). Signalling by glial cell line-derived neurotrophic factor (GDNF) requires heparan sulphate glycosaminoglycan. J Cell Sci, Vol. 115, No. Pt 23, pp. 4495-4503.

Bartus, R.T.; Herzog, C.D.; Bishop, K.; Ostrove, J.M.; Tuszynski, M.; Kordower, J.H. \& Gasmi, M. (2007). Issues regarding gene therapy products for Parkinson's disease: the development of CERE-120 (AAV-NTN) as one reference point. Parkinsonism Relat Disord, Vol. 13 Suppl 3, No. pp. S469-477. 
Bartus, R.T.; Herzog, C.D.; Chu, Y.; Wilson, A.; Brown, L.; Siffert, J.; Johnson, E.M., Jr.; Olanow, C.W.; Mufson, E.J. \& Kordower, J.H. (2011). Bioactivity of AAV2neurturin gene therapy (CERE-120): differences between Parkinson's disease and nonhuman primate brains. Mov Disord, Vol. 26, No. 1, pp. 27-36.

Bauer, M.; Meyer, M.; Grimm, L.; Meitinger, T.; Zimmer, J.; Gasser, T.; Ueffing, M. \& Widmer, H.R. (2000). Nonviral glial cell-derived neurotrophic factor gene transfer enhances survival of cultured dopaminergic neurons and improves their function after transplantation in a rat model of Parkinson's disease. Hum Gene Ther, Vol. 11, No. 11, pp. 1529-1541.

Beck, K.D.; Valverde, J.; Alexi, T.; Poulsen, K.; Moffat, B.; Vandlen, R.A.; Rosenthal, A. \& Hefti, F. (1995). Mesencephalic dopaminergic neurons protected by GDNF from axotomy-induced degeneration in the adult brain. Nature, Vol. 373, No. 6512, pp. 339-341.

Behrstock, S.; Ebert, A.; McHugh, J.; Vosberg, S.; Moore, J.; Schneider, B.; Capowski, E.; Hei, D.; Kordower, J.; Aebischer, P. \& Svendsen, C.N. (2006). Human neural progenitors deliver glial cell line-derived neurotrophic factor to parkinsonian rodents and aged primates. Gene Ther, Vol. 13, No. 5, pp. 379-388.

Bensadoun, J.C.; Pereira de Almeida, L.; Fine, E.G.; Tseng, J.L.; Deglon, N. \& Aebischer, P. (2003). Comparative study of GDNF delivery systems for the CNS: polymer rods, encapsulated cells, and lentiviral vectors. J Control Release, Vol. 87, No. 1-3, pp. 107-115.

Bespalov, M.M. \& Saarma, M. (2007). GDNF family receptor complexes are emerging drug targets. Trends Pharmacol Sci, Vol. 28, No. 2, pp. 68-74.

Bespalov, M.M.; Sidorova, Y.A.; Tumova, S.; Ahonen-Bishopp, A.; Magalhaes, A.C.; Kulesskiy, E.; Paveliev, M.; Rivera, C.; Rauvala, H. \& Saarma, M. (2011). Heparan sulfate proteoglycan syndecan-3 is a novel receptor for GDNF, neurturin, and artemin. J Cell Biol, Vol. 192, No. 1, pp. 153-169.

Bilak, M.M.; Shifrin, D.A.; Corse, A.M.; Bilak, S.R. \& Kuncl, R.W. (1999). Neuroprotective utility and neurotrophic action of neurturin in postnatal motor neurons: comparison with GDNF and persephin. Mol Cell Neurosci, Vol. 13, No. 5, pp. 326-336.

Bilang-Bleuel, A.; Revah, F.; Colin, P.; Locquet, I.; Robert, J.J.; Mallet, J. \& Horellou, P. (1997). Intrastriatal injection of an adenoviral vector expressing glial-cell-line-derived neurotrophic factor prevents dopaminergic neuron degeneration and behavioral impairment in a rat model of Parkinson disease. Proc Natl Acad Sci U S A, Vol. 94, No. 16, pp. 8818-8823.

Bjorklund, A.; Bjorklund, T. \& Kirik, D. (2009). Gene therapy for dopamine replacement in Parkinson's disease. Sci Transl Med, Vol. 1, No. 2, pp. 2ps2.

Bjorklund, A.; Kirik, D.; Rosenblad, C.; Georgievska, B.; Lundberg, C. \& Mandel, R.J. (2000). Towards a neuroprotective gene therapy for Parkinson's disease: use of adenovirus, $\mathrm{AAV}$ and lentivirus vectors for gene transfer of GDNF to the nigrostriatal system in the rat Parkinson model. Brain Res, Vol. 886, No. 1-2, pp. 82-98.

Bjorklund, A. \& Lindvall, O. (2000). Parkinson disease gene therapy moves toward the clinic. Nat Med, Vol. 6, No. 11, pp. 1207-1208.

Bjorklund, A.; Rosenblad, C.; Winkler, C. \& Kirik, D. (1997). Studies on neuroprotective and regenerative effects of GDNF in a partial lesion model of Parkinson's disease. Neurobiol Dis, Vol. 4, No. 3-4, pp. 186-200. 
Borgal, L.; Hong, M.; Sadi, D. \& Mendez, I. (2007). Differential effects of glial cell linederived neurotrophic factor on A9 and A10 dopamine neuron survival in vitro. Neuroscience, Vol. 147, No. 3, pp. 712-719.

Bowenkamp, K.E.; Hoffman, A.F.; Gerhardt, G.A.; Henry, M.A.; Biddle, P.T.; Hoffer, B.J. \& Granholm, A.C. (1995). Glial cell line-derived neurotrophic factor supports survival of injured midbrain dopaminergic neurons. J Comp Neurol, Vol. 355, No. 4, pp. 479-489.

Bowenkamp, K.E.; Lapchak, P.A.; Hoffer, B.J.; Miller, P.J. \& Bickford, P.C. (1997). Intracerebroventricular glial cell line-derived neurotrophic factor improves motor function and supports nigrostriatal dopamine neurons in bilaterally 6hydroxydopamine lesioned rats. Exp Neurol, Vol. 145, No. 1, pp. 104-117.

Braak, H.; Del Tredici, K.; Rub, U.; de Vos, R.A.; Jansen Steur, E.N. \& Braak, E. (2003). Staging of brain pathology related to sporadic Parkinson's disease. Neurobiol Aging, Vol. 24, No. 2, pp. 197-211.

Bragdon, B.; Moseychuk, O.; Saldanha, S.; King, D.; Julian, J. \& Nohe, A. (2011). Bone morphogenetic proteins: a critical review. Cell Signal, Vol. 23, No. 4, pp. 609-620.

Brundin, P.; Barker, R.A. \& Parmar, P. (2010). Neural grafting in Parkinson's disease : Problems and possibilities. Prog Brain Res, Vol. 184, pp. 265-294.

Burke, R.E.; Antonelli, M. \& Sulzer, D. (1998). Glial cell line-derived neurotrophic growth factor inhibits apoptotic death of postnatal substantia nigra dopamine neurons in primary culture. J Neurochem, Vol. 71, No. 2, pp. 517-525.

Cao, J.P.; Li, F.Z.; Zhu, Y.Y.; Yuan, H.H.; Yu, Z.Q. \& Gao, D.S. (2010). Expressions and possible roles of GDNF receptors in the developing dopaminergic neurons. Brain Res Bull, Vol. 83, No. 6, pp. 321-330.

Cao, J.P.; Wang, H.J.; Yu, J.K.; Yang, H.; Xiao, C.H. \& Gao, D.S. (2008). Involvement of NCAM in the effects of GDNF on the neurite outgrowth in the dopamine neurons. Neurosci Res, Vol. 61, No. 4, pp. 390-397.

Cass, W.A. \& Peters, L.E. (2010). Neurturin effects on nigrostriatal dopamine release and content: comparison with GDNF. Neurochem Res, Vol. 35, No. 5, pp. 727-734.

Cass, W.A.; Peters, L.E.; Harned, M.E. \& Seroogy, K.B. (2006). Protection by GDNF and other trophic factors against the dopamine-depleting effects of neurotoxic doses of methamphetamine. Ann N Y Acad Sci, Vol. 1074, No. pp. 272-281.

Choi-Lundberg, D.L. \& Bohn, M.C. (1995). Ontogeny and distribution of glial cell linederived neurotrophic factor (GDNF) mRNA in rat. Brain Res Dev Brain Res, Vol. 85, No. 1, pp. 80-88.

Choi-Lundberg, D.L.; Lin, Q.; Chang, Y.N.; Chiang, Y.L.; Hay, C.M.; Mohajeri, H.; Davidson, B.L. \& Bohn, M.C. (1997). Dopaminergic neurons protected from degeneration by GDNF gene therapy. Science, Vol. 275, No. 5301, pp. 838-841.

Choi-Lundberg, D.L.; Lin, Q.; Schallert, T.; Crippens, D.; Davidson, B.L.; Chang, Y.N.; Chiang, Y.L.; Qian, J.; Bardwaj, L. \& Bohn, M.C. (1998). Behavioral and cellular protection of rat dopaminergic neurons by an adenoviral vector encoding glial cell line-derived neurotrophic factor. Exp Neurol, Vol. 154, No. 2, pp. 261-275.

Choi, J.M.; Hong, J.H.; Chae, M.J.; Hung, N.P.; Kang, H.S.; Ma, H.I. \& Kim, Y.J. (2011). Analysis of mutations and the association between polymorphisms in the cerebral dopamine neurotrophic factor (CDNF) gene and Parkinson disease. Neurosci Lett, Vol. 493, No. 3, pp. 97-101. 
Clarkson, E.D.; Zawada, W.M. \& Freed, C.R. (1995). GDNF reduces apoptosis in dopaminergic neurons in vitro. Neuroreport, Vol. 7, No. 1, pp. 145-149.

Clarkson, E.D.; Zawada, W.M. \& Freed, C.R. (1997). GDNF improves survival and reduces apoptosis in human embryonic dopaminergic neurons in vitro. Cell Tissue Res, Vol. 289, No. 2, pp. 207-210.

Clayton, K.B. \& Sullivan, A.M. (2007). Differential effects of GDF5 on the medial and lateral rat ventral mesencephalon. Neurosci Lett, Vol. 427, No. 3, pp. 132-137.

Connor, B.; Kozlowski, D.A.; Schallert, T.; Tillerson, J.L.; Davidson, B.L. \& Bohn, M.C. (1999). Differential effects of glial cell line-derived neurotrophic factor (GDNF) in the striatum and substantia nigra of the aged Parkinsonian rat. Gene Ther, Vol. 6, No. 12, pp. 1936-1951.

Corradini, E.; Babitt, J.L. \& Lin, H.Y. (2009). The RGM/DRAGON family of BMP coreceptors. Cytokine Growth Factor Rev, Vol. 20, No. 5-6, pp. 389-398.

Date, I.; Aoi, M.; Tomita, S.; Collins, F. \& Ohmoto, T. (1998). GDNF administration induces recovery of the nigrostriatal dopaminergic system both in young and aged parkinsonian mice. Neuroreport, Vol. 9, No. 10, pp. 2365-2369.

Date, I.; Shingo, T.; Yoshida, H.; Fujiwara, K.; Kobayashi, K.; Takeuchi, A. \& Ohmoto, T. (2001). Grafting of encapsulated genetically modified cells secreting GDNF into the striatum of parkinsonian model rats. Cell Transplant, Vol. 10, No. 4-5, pp. 397-401.

Dauer, W. \& Przedborski, S. (2003). Parkinson's disease: mechanisms and models. Neuron, Vol. 39, No. 6, pp. 889-909.

Dawson, T.M. \& Dawson, V.L. (2003). Molecular pathways of neurodegeneration in Parkinson's disease. Science, Vol. 302, No. 5646, pp. 819-822.

de Caestecker, M. (2004). The transforming growth factor-beta superfamily of receptors. Cytokine Growth Factor Rev, Vol. 15, No. 1, pp. 1-11.

de Lau, L.M. \& Breteler, M.M. (2006). Epidemiology of Parkinson's disease. Lancet Neurol, Vol. 5, No. 6, pp. 525-535.

Deierborg, T.; Soulet, D.; Roybon, L.; Hall, V. \& Brundin, P. (2008). Emerging restorative treatments for Parkinson's disease. Prog Neurobiol, Vol. 85, No. 4, pp. 407-432.

Dowd, E.; Monville, C.; Torres, E.M.; Wong, L.F.; Azzouz, M.; Mazarakis, N.D. \& Dunnett, S.B. (2005). Lentivector-mediated delivery of GDNF protects complex motor functions relevant to human Parkinsonism in a rat lesion model. Eur J Neurosci, Vol. 22, No. 10, pp. 2587-2595.

Ebendal, T.; Bengtsson, H. \& Soderstrom, S. (1998). Bone morphogenetic proteins and their receptors: potential functions in the brain. J Neurosci Res, Vol. 51, No. 2, pp. 139146.

Eggert, K.; Schlegel, J.; Oertel, W.; Wurz, C.; Krieg, J.C. \& Vedder, H. (1999). Glial cell linederived neurotrophic factor protects dopaminergic neurons from 6hydroxydopamine toxicity in vitro. Neurosci Lett, Vol. 269, No. 3, pp. 178-182.

Emborg, M.E.; Moirano, J.; Raschke, J.; Bondarenko, V.; Zufferey, R.; Peng, S.; Ebert, A.D.; Joers, V.; Roitberg, B.; Holden, J.E.; Koprich, J.; Lipton, J.; Kordower, J.H. \& Aebischer, P. (2009). Response of aged parkinsonian monkeys to in vivo gene transfer of GDNF. Neurobiol Dis, Vol. 36, No. 2, pp. 303-311.

Engele, J. \& Franke, B. (1996). Effects of glial cell line-derived neurotrophic factor (GDNF) on dopaminergic neurons require concurrent activation of cAMP-dependent signaling pathways. Cell Tissue Res, Vol. 286, No. 2, pp. 235-240. 
Evans, J.R. \& Barker, R.A. (2008). Neurotrophic factors as a therapeutic target for Parkinson's disease. Expert Opin Ther Targets, Vol. 12, No. 4, pp. 437-447.

Fahn, S. \& Cohen, G. (1992). The oxidant stress hypothesis in Parkinson's disease: evidence supporting it. Ann Neurol, Vol. 32, No. 6, pp. 804-812.

Fearnley, J.M. \& Lees, A.J. (1991). Ageing and Parkinson's disease: substantia nigra regional selectivity. Brain, Vol. 114 ( Pt 5), No. pp. 2283-2301.

Fjord-Larsen, L.; Johansen, J.L.; Kusk, P.; Tornoe, J.; Gronborg, M.; Rosenblad, C. \& Wahlberg, L.U. (2005). Efficient in vivo protection of nigral dopaminergic neurons by lentiviral gene transfer of a modified Neurturin construct. Exp Neurol, Vol. 195, No. 1, pp. 49-60.

Forno, L.S. (1996). Neuropathology of Parkinson's disease. J Neuropathol Exp Neurol, Vol. 55, No. 3, pp. 259-272.

Fox, C.M.; Gash, D.M.; Smoot, M.K. \& Cass, W.A. (2001). Neuroprotective effects of GDNF against 6-OHDA in young and aged rats. Brain Res, Vol. 896, No. 1-2, pp. 56-63.

Freed, C.R.; Greene, P.E.; Breeze, R.E.; Tsai, W.Y.; DuMouchel, W.; Kao, R.; Dillon, S.; Winfield, H.; Culver, S.; Trojanowski, J.Q.; Eidelberg, D. \& Fahn, S. (2001). Transplantation of embryonic dopamine neurons for severe Parkinson's disease. N Engl J Med, Vol. 344, No. 10, pp. 710-719.

Gardell, L.R.; Wang, R.; Ehrenfels, C.; Ossipov, M.H.; Rossomando, A.J.; Miller, S.; Buckley, C.; Cai, A.K.; Tse, A.; Foley, S.F.; Gong, B.; Walus, L.; Carmillo, P.; Worley, D.; Huang, C.; Engber, T.; Pepinsky, B.; Cate, R.L.; Vanderah, T.W.; Lai, J.; Sah, D.W. \& Porreca, F. (2003). Multiple actions of systemic artemin in experimental neuropathy. Nat Med, Vol. 9, No. 11, pp. 1383-1389.

Gash, D.M.; Zhang, Z.; Cass, W.A.; Ovadia, A.; Simmerman, L.; Martin, D.; Russell, D.; Collins, F.; Hoffer, B.J. \& Gerhardt, G.A. (1995). Morphological and functional effects of intranigrally administered GDNF in normal rhesus monkeys. J Comp Neurol, Vol. 363, No. 3, pp. 345-358.

Gash, D.M.; Zhang, Z.; Ovadia, A.; Cass, W.A.; Yi, A.; Simmerman, L.; Russell, D.; Martin, D.; Lapchak, P.A.; Collins, F.; Hoffer, B.J. \& Gerhardt, G.A. (1996). Functional recovery in parkinsonian monkeys treated with GDNF. Nature, Vol. 380, No. 6571, pp. 252-255.

Gasmi, M.; Brandon, E.P.; Herzog, C.D.; Wilson, A.; Bishop, K.M.; Hofer, E.K.; Cunningham, J.J.; Printz, M.A.; Kordower, J.H. \& Bartus, R.T. (2007). AAV2-mediated delivery of human neurturin to the rat nigrostriatal system: Long-term efficacy and tolerability of CERE-120 for Parkinson's disease. Neurobiol Dis, Vol. 27, No. 1, pp. 67-76.

Gasmi, M.; Herzog, C.D.; Brandon, E.P.; Cunningham, J.J.; Ramirez, G.A.; Ketchum, E.T. \& Bartus, R.T. (2007). Striatal Delivery of Neurturin by CERE-120, an AAV2 Vector for the Treatment of Dopaminergic Neuron Degeneration in Parkinson's Disease. Mol Ther, Vol. 15, No. 1, pp. 62-68.

Gerhardt, G.A.; Cass, W.A.; Huettl, P.; Brock, S.; Zhang, Z. \& Gash, D.M. (1999). GDNF improves dopamine function in the substantia nigra but not the putamen of unilateral MPTP-lesioned rhesus monkeys. Brain Res, Vol. 817, No. 1-2, pp. 163171.

Gibb, W.R. \& Lees, A.J. (1988). The relevance of the Lewy body to the pathogenesis of idiopathic Parkinson's disease. J Neurol Neurosurg Psychiatry, Vol. 51, No. 6, pp. 745-752. 
Gill, S.S.; Patel, N.K.; Hotton, G.R.; O'Sullivan, K.; McCarter, R.; Bunnage, M.; Brooks, D.J.; Svendsen, C.N. \& Heywood, P. (2003). Direct brain infusion of glial cell linederived neurotrophic factor in Parkinson disease. Nat Med, Vol. 9, No. 5, pp. 589595.

Glazner, G.W.; Mu, X. \& Springer, J.E. (1998). Localization of glial cell line-derived neurotrophic factor receptor alpha and c-ret mRNA in rat central nervous system. J Comp Neurol, Vol. 391, No. 1, pp. 42-49.

Golden, J.P.; Baloh, R.H.; Kotzbauer, P.T.; Lampe, P.A.; Osborne, P.A.; Milbrandt, J. \& Johnson, E.M., Jr. (1998). Expression of neurturin, GDNF, and their receptors in the adult mouse CNS. J Comp Neurol, Vol. 398, No. 1, pp. 139-150.

Golden, J.P.; DeMaro, J.A.; Osborne, P.A.; Milbrandt, J. \& Johnson, E.M., Jr. (1999). Expression of neurturin, GDNF, and GDNF family-receptor mRNA in the developing and mature mouse. Exp Neurol, Vol. 158, No. 2, pp. 504-528.

Granholm, A.C.; Mott, J.L.; Bowenkamp, K.; Eken, S.; Henry, S.; Hoffer, B.J.; Lapchak, P.A.; Palmer, M.R.; van Horne, C. \& Gerhardt, G.A. (1997). Glial cell line-derived neurotrophic factor improves survival of ventral mesencephalic grafts to the 6hydroxydopamine lesioned striatum. Exp Brain Res, Vol. 116, No. 1, pp. 29-38.

Grondin, R.; Zhang, Z.; Ai, Y.; Ding, F.; Walton, A.A.; Surgener, S.P.; Gerhardt, G.A. \& Gash, D.M. (2008). Intraputamenal infusion of exogenous neurturin protein restores motor and dopaminergic function in the globus pallidus of MPTP-lesioned rhesus monkeys. Cell Transplant, Vol. 17, No. 4, pp. 373-381.

Grondin, R.; Zhang, Z.; Yi, A.; Cass, W.A.; Maswood, N.; Andersen, A.H.; Elsberry, D.D.; Klein, M.C.; Gerhardt, G.A. \& Gash, D.M. (2002). Chronic, controlled GDNF infusion promotes structural and functional recovery in advanced parkinsonian monkeys. Brain, Vol. 125, No. Pt 10, pp. 2191-2201.

Hagell, P.; Piccini, P.; Bjorklund, A.; Brundin, P.; Rehncrona, S.; Widner, H.; Crabb, L.; Pavese, N.; Oertel, W.H.; Quinn, N.; Brooks, D.J. \& Lindvall, O. (2002). Dyskinesias following neural transplantation in Parkinson's disease. Nat Neurosci, Vol. 5, No. 7, pp. 627-628.

Hall, A.K. \& Miller, R.H. (2004). Emerging roles for bone morphogenetic proteins in central nervous system glial biology. J Neurosci Res, Vol. 76, No. 1, pp. 1-8.

Hedlund, E. \& Perlmann, T. (2009) Neuronal cell replacement in Parkinson's disease. Intern Med. Vol. 266, No. 4, pp. 358-371.

Hellman, M.; Arumae, U.; Yu, L.Y.; Lindholm, P.; Peranen, J.; Saarma, M. \& Permi, P. (2011). Mesencephalic astrocyte-derived neurotrophic factor (MANF) has a unique mechanism to rescue apoptotic neurons. J Biol Chem, Vol. 286, No. 4, pp. 26752680.

Hermann, D.M.; Kilic, E.; Kugler, S.; Isenmann, S. \& Bahr, M. (2001). Adenovirus-mediated glial cell line-derived neurotrophic factor (GDNF) expression protects against subsequent cortical cold injury in rats. Neurobiol Dis, Vol. 8, No. 6, pp. 964-973.

Herzog, C.D.; Brown, L.; Gammon, D.; Kruegel, B.; Lin, R.; Wilson, A.; Bolton, A.; Printz, M.; Gasmi, M.; Bishop, K.M.; Kordower, J.H. \& Bartus, R.T. (2009). Expression, bioactivity, and safety 1 year after adeno-associated viral vector type 2-mediated delivery of neurturin to the monkey nigrostriatal system support cere-120 for Parkinson's disease. Neurosurgery, Vol. 64, No. 4, pp. 602-612; discussion 612-603. 
Herzog, C.D.; Dass, B.; Holden, J.E.; Stansell, J., 3rd; Gasmi, M.; Tuszynski, M.H.; Bartus, R.T. \& Kordower, J.H. (2007). Striatal delivery of CERE-120, an AAV2 vector encoding human neurturin, enhances activity of the dopaminergic nigrostriatal system in aged monkeys. Mov Disord, Vol. 22, No. 8, pp. 1124-1132.

Hoane, M.R.; Gulwadi, A.G.; Morrison, S.; Hovanesian, G.; Lindner, M.D. \& Tao, W. (1999). Differential in vivo effects of neurturin and glial cell-line-derived neurotrophic factor. Exp Neurol, Vol. 160, No. 1, pp. 235-243.

Hoehn, M.M. \& Yahr, M.D. (1967). Parkinsonism: onset, progression and mortality. Neurology, Vol. 17, No. 5, pp. 427-442.

Hoffer, B.J.; Hoffman, A.; Bowenkamp, K.; Huettl, P.; Hudson, J.; Martin, D.; Lin, L.F. \& Gerhardt, G.A. (1994). Glial cell line-derived neurotrophic factor reverses toxininduced injury to midbrain dopaminergic neurons in vivo. Neurosci Lett, Vol. 182, No. 1, pp. 107-111.

Hogan, B.L. (1996). Bone morphogenetic proteins: multifunctional regulators of vertebrate development. Genes Dev, Vol. 10, No. 13, pp. 1580-1594.

Horger, B.A.; Nishimura, M.C.; Armanini, M.P.; Wang, L.C.; Poulsen, K.T.; Rosenblad, C.; Kirik, D.; Moffat, B.; Simmons, L.; Johnson, E., Jr.; Milbrandt, J.; Rosenthal, A.; Bjorklund, A.; Vandlen, R.A.; Hynes, M.A. \& Phillips, H.S. (1998). Neurturin exerts potent actions on survival and function of midbrain dopaminergic neurons. J Neurosci, Vol. 18, No. 13, pp. 4929-4937.

Hou, J.G.; Lin, L.F. \& Mytilineou, C. (1996). Glial cell line-derived neurotrophic factor exerts neurotrophic effects on dopaminergic neurons in vitro and promotes their survival and regrowth after damage by 1-methyl-4-phenylpyridinium. J Neurochem, Vol. 66, No. 1, pp. 74-82.

Hovland, D.N., Jr.; Boyd, R.B.; Butt, M.T.; Engelhardt, J.A.; Moxness, M.S.; Ma, M.H.; Emery, M.G.; Ernst, N.B.; Reed, R.P.; Zeller, J.R.; Gash, D.M.; Masterman, D.M.; Potter, B.M.; Cosenza, M.E. \& Lightfoot, R.M. (2007). Six-month continuous intraputamenal infusion toxicity study of recombinant methionyl human glial cell line-derived neurotrophic factor (r-metHuGDNF) in rhesus monkeys. Toxicol Pathol, Vol. 35, No. 5, pp. 676-692.

Hurley, F.M.; Costello, D.J. \& Sullivan, A.M. (2004). Neuroprotective effects of delayed administration of growth/differentiation factor-5 in the partial lesion model of Parkinson's disease. Exp Neurol, Vol. 185, No. 2, pp. 281-289.

Iravani, M.M.; Costa, S.; Jackson, M.J.; Tel, B.C.; Cannizzaro, C.; Pearce, R.K. \& Jenner, P. (2001). GDNF reverses priming for dyskinesia in MPTP-treated, L-DOPA-primed common marmosets. Eur J Neurosci, Vol. 13, No. 3, pp. 597-608.

Kawabata, M.; Imamura, T. \& Miyazono, K. (1998). Signal transduction by bone morphogenetic proteins. Cytokine Growth Factor Rev, Vol. 9, No. 1, pp. 49-61.

Kearns, C.M. \& Gash, D.M. (1995). GDNF protects nigral dopamine neurons against 6hydroxydopamine in vivo. Brain Res, Vol. 672, No. 1-2, pp. 104-111.

Kirik, D.; Rosenblad, C.; Bjorklund, A. \& Mandel, R.J. (2000). Long-term rAAV-mediated gene transfer of GDNF in the rat Parkinson's model: intrastriatal but not intranigral transduction promotes functional regeneration in the lesioned nigrostriatal system. J Neurosci, Vol. 20, No. 12, pp. 4686-4700. 
Kirik, D.; Winkler, C. \& Bjorklund, A. (2001). Growth and functional efficacy of intrastriatal nigral transplants depend on the extent of nigrostriatal degeneration. J Neurosci, Vol. 21, No. 8, pp. 2889-2896.

Kishima, H.; Poyot, T.; Bloch, J.; Dauguet, J.; Conde, F.; Dolle, F.; Hinnen, F.; Pralong, W.; Palfi, S.; Deglon, N.; Aebischer, P. \& Hantraye, P. (2004). Encapsulated GDNFproducing $\mathrm{C} 2 \mathrm{C} 12$ cells for Parkinson's disease: a pre-clinical study in chronic MPTP-treated baboons. Neurobiol Dis, Vol. 16, No. 2, pp. 428-439.

Kojima, H.; Abiru, Y.; Sakajiri, K.; Watabe, K.; Ohishi, N.; Takamori, M.; Hatanaka, H. \& Yagi, K. (1997). Adenovirus-mediated transduction with human glial cell linederived neurotrophic factor gene prevents 1-methyl-4-phenyl-1,2,3,6tetrahydropyridine-induced dopamine depletion in striatum of mouse brain. Biochem Biophys Res Commun, Vol. 238, No. 2, pp. 569-573.

Kordower, J.H. (2003). In vivo gene delivery of glial cell line--derived neurotrophic factor for Parkinson's disease. Ann Neurol, Vol. 53 Suppl 3, No. pp. S120-132; discussion S132-124.

Kordower, J.H.; Emborg, M.E.; Bloch, J.; Ma, S.Y.; Chu, Y.; Leventhal, L.; McBride, J.; Chen, E.Y.; Palfi, S.; Roitberg, B.Z.; Brown, W.D.; Holden, J.E.; Pyzalski, R.; Taylor, M.D.; Carvey, P.; Ling, Z.; Trono, D.; Hantraye, P.; Deglon, N. \& Aebischer, P. (2000). Neurodegeneration prevented by lentiviral vector delivery of GDNF in primate models of Parkinson's disease. Science, Vol. 290, No. 5492, pp. 767-773.

Kordower, J.H.; Herzog, C.D.; Dass, B.; Bakay, R.A.; Stansell, J., 3rd; Gasmi, M. \& Bartus, R.T. (2006). Delivery of neurturin by AAV2 (CERE-120)-mediated gene transfer provides structural and functional neuroprotection and neurorestoration in MPTPtreated monkeys. Ann Neurol, Vol. 60, No. 6, pp. 706-715.

Kordower, J.H.; Palfi, S.; Chen, E.Y.; Ma, S.Y.; Sendera, T.; Cochran, E.J.; Mufson, E.J.; Penn, R.; Goetz, C.G. \& Comella, C.D. (1999). Clinicopathological findings following intraventricular glial-derived neurotrophic factor treatment in a patient with Parkinson's disease. Ann Neurol, Vol. 46, No. 3, pp. 419-424.

Kotzbauer, P.T.; Lampe, P.A.; Heuckeroth, R.O.; Golden, J.P.; Creedon, D.J.; Johnson, E.M., Jr. \& Milbrandt, J. (1996). Neurturin, a relative of glial-cell-line-derived neurotrophic factor. Nature, Vol. 384, No. 6608, pp. 467-470.

Kozlowski, D.A.; Connor, B.; Tillerson, J.L.; Schallert, T. \& Bohn, M.C. (2000). Delivery of a GDNF gene into the substantia nigra after a progressive 6-OHDA lesion maintains functional nigrostriatal connections. Exp Neurol, Vol. 166, No. 1, pp. 1-15.

Kramer, B.C.; Goldman, A.D. \& Mytilineou, C. (1999). Glial cell line derived neurotrophic factor promotes the recovery of dopamine neurons damaged by 6hydroxydopamine in vitro. Brain Res, Vol. 851, No. 1-2, pp. 221-227.

Krieglstein, K.; Henheik, P.; Farkas, L.; Jaszai, J.; Galter, D.; Krohn, K. \& Unsicker, K. (1998). Glial cell line-derived neurotrophic factor requires transforming growth factor-beta for exerting its full neurotrophic potential on peripheral and CNS neurons. J Neurosci, Vol. 18, No. 23, pp. 9822-9834.

Krieglstein, K.; Strelau, J.; Schober, A.; Sullivan, A. \& Unsicker, K. (2002). TGF-beta and the regulation of neuron survival and death. J Physiol Paris, Vol. 96, No. 1-2, pp. 25-30.

Krieglstein, K.; Suter-Crazzolara, C.; Fischer, W.H. \& Unsicker, K. (1995). TGF-beta superfamily members promote survival of midbrain dopaminergic neurons and protect them against MPP+ toxicity. Embo J, Vol. 14, No. 4, pp. 736-742. 
Krieglstein, K.; Suter-Crazzolara, C.; Hotten, G.; Pohl, J. \& Unsicker, K. (1995). Trophic and protective effects of growth/differentiation factor 5, a member of the transforming growth factor-beta superfamily, on midbrain dopaminergic neurons. J Neurosci Res, Vol. 42, No. 5, pp. 724-732.

Lang, A.E.; Gill, S.; Patel, N.K.; Lozano, A.; Nutt, J.G.; Penn, R.; Brooks, D.J.; Hotton, G.; Moro, E.; Heywood, P.; Brodsky, M.A.; Burchiel, K.; Kelly, P.; Dalvi, A.; Scott, B.; Stacy, M.; Turner, D.; Wooten, V.G.; Elias, W.J.; Laws, E.R.; Dhawan, V.; Stoessl, A.J.; Matcham, J.; Coffey, R.J. \& Traub, M. (2006). Randomized controlled trial of intraputamenal glial cell line-derived neurotrophic factor infusion in Parkinson disease. Ann Neurol, Vol. 59, No. 3, pp. 459-466.

Lang, A.E.; Langston, J.W.; Stoessl, A.J.; Brodsky, M.; Brooks, D.J.; Dhawan, V.; Elias, W.J.; Lozano, A.M.; Moro, E.; Nutt, J.G.; Stacy, M.; Turner, D. \& Wooten, G.F. (2006). GDNF in treatment of Parkinson's disease: response to editorial. Lancet Neurol, Vol. 5, No. 3, pp. 200-202.

Lapchak, P.A.; Araujo, D.M.; Hilt, D.C.; Sheng, J. \& Jiao, S. (1997). Adenoviral vectormediated GDNF gene therapy in a rodent lesion model of late stage Parkinson's disease. Brain Res, Vol. 777, No. 1-2, pp. 153-160.

Lee, R.; Kermani, P.; Teng, K.K. \& Hempstead, B.L. (2001). Regulation of cell survival by secreted proneurotrophins. Science, Vol. 294, No. 5548, pp. 1945-1948.

Leitner, M.L.; Molliver, D.C.; Osborne, P.A.; Vejsada, R.; Golden, J.P.; Lampe, P.A.; Kato, A.C.; Milbrandt, J. \& Johnson, E.M., Jr. (1999). Analysis of the retrograde transport of glial cell line-derived neurotrophic factor (GDNF), neurturin, and persephin suggests that in vivo signaling for the GDNF family is GFRalpha coreceptorspecific. J Neurosci, Vol. 19, No. 21, pp. 9322-9331.

Li, H.; He, Z.; Su, T.; Ma, Y.; Lu, S.; Dai, C. \& Sun, M. (2003). Protective action of recombinant neurturin on dopaminergic neurons in substantia nigra in a rhesus monkey model of Parkinson's disease. Neurol Res, Vol. 25, No. 3, pp. 263-267.

Lin, L.F.; Doherty, D.H.; Lile, J.D.; Bektesh, S. \& Collins, F. (1993). GDNF: a glial cell linederived neurotrophic factor for midbrain dopaminergic neurons. Science, Vol. 260, No. 5111, pp. 1130-1132.

Lindholm, P.; Peranen, J.; Andressoo, J.O.; Kalkkinen, N.; Kokaia, Z.; Lindvall, O.; Timmusk, T. \& Saarma, M. (2008). MANF is widely expressed in mammalian tissues and differently regulated after ischemic and epileptic insults in rodent brain. Mol Cell Neurosci, Vol. 39, No. 3, pp. 356-371.

Lindholm, P. \& Saarma, M. (2010). Novel CDNF/MANF family of neurotrophic factors. Dev Neurobiol, Vol. 70, No. 5, pp. 360-371.

Lindholm, P.; Voutilainen, M.H.; Lauren, J.; Peranen, J.; Leppanen, V.M.; Andressoo, J.O.; Lindahl, M.; Janhunen, S.; Kalkkinen, N.; Timmusk, T.; Tuominen, R.K. \& Saarma, M. (2007). Novel neurotrophic factor CDNF protects and rescues midbrain dopamine neurons in vivo. Nature, Vol. 448, No. 7149, pp. 73-77.

Lindvall, O. \& Wahlberg, L.U. (2008). Encapsulated cell biodelivery of GDNF: a novel clinical strategy for neuroprotection and neuroregeneration in Parkinson's disease? Exp Neurol, Vol. 209, No. 1, pp. 82-88.

Lingor, P.; Unsicker, K. \& Krieglstein, K. (1999). Midbrain dopaminergic neurons are protected from radical induced damage by GDF-5 application. Short communication. J Neural Transm, Vol. 106, No. 2, pp. 139-144. 
Little, S.C. \& Mullins, M.C. (2009). Bone morphogenetic protein heterodimers assemble heteromeric type I receptor complexes to pattern the dorsoventral axis. Nat Cell Biol, Vol. 11, No. 5, pp. 637-643.

Long-Smith, C.M.; Sullivan, A.M. \& Nolan, Y.M. (2009). The influence of microglia on the pathogenesis of Parkinson's disease. Prog Neurobiol, Vol. 89, No. 3, pp. 277-287.

Love, S.; Plaha, P.; Patel, N.K.; Hotton, G.R.; Brooks, D.J. \& Gill, S.S. (2005). Glial cell linederived neurotrophic factor induces neuronal sprouting in human brain. Nat Med, Vol. 11, No. 7, pp. 703-704.

Ma, D.; Wang, X. \& Han, J. (2000). NIH 3T3 cells or engineered NIH 3 T3 cells stably expressing GDNF can protect primary dopaminergic neurons. Neurol Res, Vol. 22, No. 6, pp. 538-544.

Mandel, R.J.; Snyder, R.O. \& Leff, S.E. (1999). Recombinant adeno-associated viral vectormediated glial cell line-derived neurotrophic factor gene transfer protects nigral dopamine neurons after onset of progressive degeneration in a rat model of Parkinson's disease. Exp Neurol, Vol. 160, No. 1, pp. 205-214.

Mandel, R.J.; Spratt, S.K.; Snyder, R.O. \& Leff, S.E. (1997). Midbrain injection of recombinant adeno-associated virus encoding rat glial cell line-derived neurotrophic factor protects nigral neurons in a progressive 6-hydroxydopamine-induced degeneration model of Parkinson's disease in rats. Proc Natl Acad Sci U S A, Vol. 94, No. 25, pp. 14083-14088.

Manfredsson, F.P.; Okun, M.S. \& Mandel, R.J. (2009). Gene therapy for neurological disorders: challenges and future prospects for the use of growth factors for the treatment of Parkinson's disease. Curr Gene Ther, Vol. 9, No. 5, pp. 375-388.

Marks, W.J., Jr.; Bartus, R.T.; Siffert, J.; Davis, C.S.; Lozano, A.; Boulis, N.; Vitek, J.; Stacy, M.; Turner, D.; Verhagen, L.; Bakay, R.; Watts, R.; Guthrie, B.; Jankovic, J.; Simpson, R.; Tagliati, M.; Alterman, R.; Stern, M.; Baltuch, G.; Starr, P.A.; Larson, P.S.; Ostrem, J.L.; Nutt, J.; Kieburtz, K.; Kordower, J.H. \& Olanow, C.W. (2010). Gene delivery of AAV2-neurturin for Parkinson's disease: a double-blind, randomised, controlled trial. Lancet Neurol, Vol. 9, No. 12, pp. 1164-1172.

Marks, W.J., Jr.; Ostrem, J.L.; Verhagen, L.; Starr, P.A.; Larson, P.S.; Bakay, R.A.; Taylor, R.; Cahn-Weiner, D.A.; Stoessl, A.J.; Olanow, C.W. \& Bartus, R.T. (2008). Safety and tolerability of intraputaminal delivery of CERE-120 (adeno-associated virus serotype 2-neurturin) to patients with idiopathic Parkinson's disease: an openlabel, phase I trial. Lancet Neurol, Vol. 7, No. 5, pp. 400-408.

Martin, D.; Miller, G.; Cullen, T.; Fischer, N.; Dix, D. \& Russell, D. (1996). Intranigral or intrastriatal injections of GDNF: effects on monoamine levels and behavior in rats. Eur J Pharmacol, Vol. 317, No. 2-3, pp. 247-256.

Massague, J. (1996). TGFbeta signaling: receptors, transducers, and Mad proteins. Cell, Vol. 85, No. 7, pp. 947-950.

Massague, J.; Seoane, J. \& Wotton, D. (2005). Smad transcription factors. Genes Dev, Vol. 19, No. 23, pp. 2783-2810.

Maswood, N.; Grondin, R.; Zhang, Z.; Stanford, J.A.; Surgener, S.P.; Gash, D.M. \& Gerhardt, G.A. (2002). Effects of chronic intraputamenal infusion of glial cell line-derived neurotrophic factor (GDNF) in aged Rhesus monkeys. Neurobiol Aging, Vol. 23, No. 5, pp. 881-889. 
Matsuo, A.; Nakamura, S. \& Akiguchi, I. (2000). Immunohistochemical localization of glial cell line-derived neurotrophic factor family receptor alpha-1 in the rat brain: confirmation of expression in various neuronal systems. Brain Res, Vol. 859, No. 1, pp. 57-71.

McBride, J.L.; During, M.J.; Wuu, J.; Chen, E.Y.; Leurgans, S.E. \& Kordower, J.H. (2003). Structural and functional neuroprotection in a rat model of Huntington's disease by viral gene transfer of GDNF. Exp Neurol, Vol. 181, No. 2, pp. 213-223.

McBride, J.L.; Ramaswamy, S.; Gasmi, M.; Bartus, R.T.; Herzog, C.D.; Brandon, E.P.; Zhou, L.; Pitzer, M.R.; Berry-Kravis, E.M. \& Kordower, J.H. (2006). Viral delivery of glial cell line-derived neurotrophic factor improves behavior and protects striatal neurons in a mouse model of Huntington's disease. Proc Natl Acad Sci U S A, Vol. 103, No. 24, pp. 9345-9350.

Mehler, M.F.; Mabie, P.C.; Zhang, D. \& Kessler, J.A. (1997). Bone morphogenetic proteins in the nervous system. Trends Neurosci, Vol. 20, No. 7, pp. 309-317.

Mehta, V.; Hong, M.; Spears, J. \& Mendez, I. (1998). Enhancement of graft survival and sensorimotor behavioral recovery in rats undergoing transplantation with dopaminergic cells exposed to glial cell line-derived neurotrophic factor. J Neurosurg, Vol. 88, No. 6, pp. 1088-1095.

Mendez, I.; Dagher, A.; Hong, M.; Hebb, A.; Gaudet, P.; Law, A.; Weerasinghe, S.; King, D.; Desrosiers, J.; Darvesh, S.; Acorn, T. \& Robertson, H. (2000). Enhancement of survival of stored dopaminergic cells and promotion of graft survival by exposure of human fetal nigral tissue to glial cell line--derived neurotrophic factor in patients with Parkinson's disease. Report of two cases and technical considerations. J Neurosurg, Vol. 92, No. 5, pp. 863-869.

Milbrandt, J.; de Sauvage, F.J.; Fahrner, T.J.; Baloh, R.H.; Leitner, M.L.; Tansey, M.G.; Lampe, P.A.; Heuckeroth, R.O.; Kotzbauer, P.T.; Simburger, K.S.; Golden, J.P.; Davies, J.A.; Vejsada, R.; Kato, A.C.; Hynes, M.; Sherman, D.; Nishimura, M.; Wang, L.C.; Vandlen, R.; Moffat, B.; Klein, R.D.; Poulsen, K.; Gray, C.; Garces, A.; Johnson, E.M., Jr. \& et al. (1998). Persephin, a novel neurotrophic factor related to GDNF and neurturin. Neuron, Vol. 20, No. 2, pp. 245-253.

Miyazono, K. (1999). Signal transduction by bone morphogenetic protein receptors: functional roles of Smad proteins. Bone, Vol. 25, No. 1, pp. 91-93.

Miyazono, K.; Kusanagi, K. \& Inoue, H. (2001). Divergence and convergence of TGFbeta/BMP signaling. J Cell Physiol, Vol. 187, No. 3, pp. 265-276.

Miyoshi, Y.; Zhang, Z.; Ovadia, A.; Lapchak, P.A.; Collins, F.; Hilt, D.; Lebel, C.; Kryscio, R. \& Gash, D.M. (1997). Glial cell line-derived neurotrophic factor-levodopa interactions and reduction of side effects in parkinsonian monkeys. Ann Neurol, Vol. 42, No. 2, pp. 208-214.

Morrison, P.F.; Lonser, R.R. \& Oldfield, E.H. (2007). Convective delivery of glial cell linederived neurotrophic factor in the human putamen. J Neurosurg, Vol. 107, No. 1, pp. 74-83.

Nishitoh, H.; Ichijo, H.; Kimura, M.; Matsumoto, T.; Makishima, F.; Yamaguchi, A.; Yamashita, H.; Enomoto, S. \& Miyazono, K. (1996). Identification of type I and type II serine/threonine kinase receptors for growth/differentiation factor-5. J Biol Chem, Vol. 271, No. 35, pp. 21345-21352. 
Nohe, A.; Keating, E.; Knaus, P. \& Petersen, N.O. (2004). Signal transduction of bone morphogenetic protein receptors. Cell Signal, Vol. 16, No. 3, pp. 291-299.

Nosrat, C.A.; Tomac, A.; Hoffer, B.J. \& Olson, L. (1997). Cellular and developmental patterns of expression of Ret and glial cell line-derived neurotrophic factor receptor alpha mRNAs. Exp Brain Res, Vol. 115, No. 3, pp. 410-422.

Nutt, J.G.; Burchiel, K.J.; Comella, C.L.; Jankovic, J.; Lang, A.E.; Laws, E.R., Jr.; Lozano, A.M.; Penn, R.D.; Simpson, R.K., Jr.; Stacy, M. \& Wooten, G.F. (2003). Randomized, double-blind trial of glial cell line-derived neurotrophic factor (GDNF) in PD. Neurology, Vol. 60, No. 1, pp. 69-73.

O'Keeffe, G.W.; Dockery, P. \& Sullivan, A.M. (2004). Effects of growth/differentiation factor 5 on the survival and morphology of embryonic rat midbrain dopaminergic neurones in vitro. J Neurocytol, Vol. 33, No. 5, pp. 479-488.

O'Keeffe, G.W.; Hanke, M.; Pohl, J. \& Sullivan, A.M. (2004). Expression of growth differentiation factor-5 in the developing and adult rat brain. Brain Res Dev Brain Res, Vol. 151, No. 1-2, pp. 199-202.

O'Sullivan, D.B.; Harrison, P.T. \& Sullivan, A.M. (2010). Effects of GDF5 overexpression on embryonic rat dopaminergic neurones in vitro and in vivo. J Neural Transm, Vol. 117, No. 5, pp. 559-572.

Oiwa, Y.; Yoshimura, R.; Nakai, K. \& Itakura, T. (2002). Dopaminergic neuroprotection and regeneration by neurturin assessed by using behavioral, biochemical and histochemical measurements in a model of progressive Parkinson's disease. Brain Res, Vol. 947, No. 2, pp. 271-283.

Olanow, C.W.; Kordower, J.H.; Lang, A.E. \& Obeso, J.A. (2009). Dopaminergic transplantation for Parkinson's disease: current status and future prospects. Ann Neurol. Vol. 66, No. 5, pp. 591-596.

Olanow, C.W. \& Tatton, W.G. (1999). Etiology and pathogenesis of Parkinson's disease. Annu Rev Neurosci, Vol. 22, No. pp. 123-144.

Opacka-Juffry, J.; Ashworth, S.; Hume, S.P.; Martin, D.; Brooks, D.J. \& Blunt, S.B. (1995). GDNF protects against 6-OHDA nigrostriatal lesion: in vivo study with microdialysis and PET. Neuroreport, Vol. 7, No. 1, pp. 348-352.

Ostenfeld, T.; Tai, Y.T.; Martin, P.; Deglon, N.; Aebischer, P. \& Svendsen, C.N. (2002). Neurospheres modified to produce glial cell line-derived neurotrophic factor increase the survival of transplanted dopamine neurons. J Neurosci Res, Vol. 69, No. 6, pp. 955-965.

Palfi, S.; Leventhal, L.; Chu, Y.; Ma, S.Y.; Emborg, M.; Bakay, R.; Deglon, N.; Hantraye, P.; Aebischer, P. \& Kordower, J.H. (2002). Lentivirally delivered glial cell line-derived neurotrophic factor increases the number of striatal dopaminergic neurons in primate models of nigrostriatal degeneration. J Neurosci, Vol. 22, No. 12, pp. $4942-$ 4954.

Palgi, M.; Lindstrom, R.; Peranen, J.; Piepponen, T.P.; Saarma, M. \& Heino, T.I. (2009). Evidence that DmMANF is an invertebrate neurotrophic factor supporting dopaminergic neurons. Proc Natl Acad Sci U S A, Vol. 106, No. 7, pp. 2429-2434.

Paratcha, G. \& Ledda, F. (2008). GDNF and GFRalpha: a versatile molecular complex for developing neurons. Trends Neurosci, Vol. 31, No. 8, pp. 384-391. 
Paratcha, G.; Ledda, F. \& Ibanez, C.F. (2003). The neural cell adhesion molecule NCAM is an alternative signaling receptor for GDNF family ligands. Cell, Vol. 113, No. 7, pp. 867-879.

Patel, N.K.; Bunnage, M.; Plaha, P.; Svendsen, C.N.; Heywood, P. \& Gill, S.S. (2005). Intraputamenal infusion of glial cell line-derived neurotrophic factor in PD: A twoyear outcome study. Ann Neurol, Vol. 57, No. 2, pp. 298-302.

Penn, R.D.; Dalvi, A.; Slevin, J.; Young, B.; Gash, D.; Gerhardt, G. \& Hutchinson, M. (2006). GDNF in treatment of Parkinson's disease: response to editorial. Lancet Neurol, Vol. 5, No. 3, pp. 202-203.

Perez-Navarro, E.; Akerud, P.; Marco, S.; Canals, J.M.; Tolosa, E.; Arenas, E. \& Alberch, J. (2000). Neurturin protects striatal projection neurons but not interneurons in a rat model of Huntington's disease. Neuroscience, Vol. 98, No. 1, pp. 89-96.

Peterziel, H.; Unsicker, K. \& Krieglstein, K. (2002). TGFbeta induces GDNF responsiveness in neurons by recruitment of GFRalpha1 to the plasma membrane. J Cell Biol, Vol. 159, No. 1, pp. 157-167.

Petrova, P.; Raibekas, A.; Pevsner, J.; Vigo, N.; Anafi, M.; Moore, M.K.; Peaire, A.E.; Shridhar, V.; Smith, D.I.; Kelly, J.; Durocher, Y. \& Commissiong, J.W. (2003). MANF: a new mesencephalic, astrocyte-derived neurotrophic factor with selectivity for dopaminergic neurons. J Mol Neurosci, Vol. 20, No. 2, pp. 173-188.

Poulsen, K.T.; Armanini, M.P.; Klein, R.D.; Hynes, M.A.; Phillips, H.S. \& Rosenthal, A. (1994). TGF beta 2 and TGF beta 3 are potent survival factors for midbrain dopaminergic neurons. Neuron, Vol. 13, No. 5, pp. 1245-1252.

Ramaswamy, S.; McBride, J.L.; Han, I.; Berry-Kravis, E.M.; Zhou, L.; Herzog, C.D.; Gasmi, M.; Bartus, R.T. \& Kordower, J.H. (2009). Intrastriatal CERE-120 (AAV-Neurturin) protects striatal and cortical neurons and delays motor deficits in a transgenic mouse model of Huntington's disease. Neurobiol Dis, Vol. 34, No. 1, pp. 40-50.

Ramaswamy, S.; Soderstrom, K.E. \& Kordower, J.H. (2009). Trophic factors therapy in Parkinson's disease. Prog Brain Res, Vol. 175, No. pp. 201-216.

Ramirez, F. \& Rifkin, D.B. (2009). Extracellular microfibrils: contextual platforms for TGFbeta and BMP signaling. Curr Opin Cell Biol, Vol. 21, No. 5, pp. 616-622.

Richardson, R.M.; Kells, A.P.; Rosenbluth, K.H.; Salegio, E.A.; Fiandaca, M.S.; Larson, P.S.; Starr, P.A.; Martin, A.J.; Lonser, R.R.; Federoff, H.J.; Forsayeth, J.R. \& Bankiewicz, K.S. (2011). Interventional MRI-guided Putaminal Delivery of AAV2-GDNF for a Planned Clinical Trial in Parkinson's Disease. Mol Ther, Vol. No. pp.

Rider, C.C. \& Mulloy, B. (2011). Bone morphogenetic protein and growth differentiation factor cytokine families and their protein antagonists. Biochem J, Vol. 429, No. 1, pp. 1-12.

Rosenblad, C.; Kirik, D. \& Bjorklund, A. (1999). Neurturin enhances the survival of intrastriatal fetal dopaminergic transplants. Neuroreport, Vol. 10, No. 8, pp. 17831787.

Rosenblad, C.; Kirik, D. \& Bjorklund, A. (2000). Sequential administration of GDNF into the substantia nigra and striatum promotes dopamine neuron survival and axonal sprouting but not striatal reinnervation or functional recovery in the partial 6OHDA lesion model. Exp Neurol, Vol. 161, No. 2, pp. 503-516.

Rosenblad, C.; Kirik, D.; Devaux, B.; Moffat, B.; Phillips, H.S. \& Bjorklund, A. (1999). Protection and regeneration of nigral dopaminergic neurons by neurturin or GDNF 
in a partial lesion model of Parkinson's disease after administration into the striatum or the lateral ventricle. Eur J Neurosci, Vol. 11, No. 5, pp. 1554-1566.

Rosenblad, C.; Martinez-Serrano, A. \& Bjorklund, A. (1996). Glial cell line-derived neurotrophic factor increases survival, growth and function of intrastriatal fetal nigral dopaminergic grafts. Neuroscience, Vol. 75, No. 4, pp. 979-985.

Rosenblad, C.; Martinez-Serrano, A. \& Bjorklund, A. (1998). Intrastriatal glial cell linederived neurotrophic factor promotes sprouting of spared nigrostriatal dopaminergic afferents and induces recovery of function in a rat model of Parkinson's disease. Neuroscience, Vol. 82, No. 1, pp. 129-137.

Roussa, E.; von Bohlen und Halbach, O. \& Krieglstein, K. (2009). TGF-beta in dopamine neuron development, maintenance and neuroprotection. Adv Exp Med Biol, Vol. 651, No. pp. 81-90.

Sajadi, A.; Bensadoun, J.C.; Schneider, B.L.; Lo Bianco, C. \& Aebischer, P. (2006). Transient striatal delivery of GDNF via encapsulated cells leads to sustained behavioral improvement in a bilateral model of Parkinson disease. Neurobiol Dis, Vol. 22, No. 1, pp. 119-129.

Sarabi, A.; Chang, C.F.; Wang, Y.; Hoffer, B.J. \& Morales, M. (2001). Time course study of GFRalpha-1 expression in an animal model of stroke. Exp Neurol, Vol. 170, No. 2, pp. 283-289.

Sariola, H. \& Saarma, M. (2003). Novel functions and signalling pathways for GDNF. J Cell Sci, Vol. 116, No. Pt 19, pp. 3855-3862.

Sauer, H. \& Oertel, W.H. (1994). Progressive degeneration of nigrostriatal dopamine neurons following intrastriatal terminal lesions with 6-hydroxydopamine: a combined retrograde tracing and immunocytochemical study in the rat. , Neurosci, Vol. 59, No. 2, pp. 401-415.

Sauer, H.; Rosenblad, C. \& Bjorklund, A. (1995). Glial cell line-derived neurotrophic factor but not transforming growth factor beta 3 prevents delayed degeneration of nigral dopaminergic neurons following striatal 6-hydroxydopamine lesion. Proc Natl Acad Sci U S A, Vol. 92, No. 19, pp. 8935-8939.

Sautter, J.; Tseng, J.L.; Braguglia, D.; Aebischer, P.; Spenger, C.; Seiler, R.W.; Widmer, H.R. \& Zurn, A.D. (1998). Implants of polymer-encapsulated genetically modified cells releasing glial cell line-derived neurotrophic factor improve survival, growth, and function of fetal dopaminergic grafts. Exp Neurol, Vol. 149, No. 1, pp. 230-236.

Sawada, H.; Ibi, M.; Kihara, T.; Urushitani, M.; Nakanishi, M.; Akaike, A. \& Shimohama, S. (2000). Neuroprotective mechanism of glial cell line-derived neurotrophic factor in mesencephalic neurons. J Neurochem, Vol. 74, No. 3, pp. 1175-1184.

Schmeer, C.; Straten, G.; Kugler, S.; Gravel, C.; Bahr, M. \& Isenmann, S. (2002). Dosedependent rescue of axotomized rat retinal ganglion cells by adenovirus-mediated expression of glial cell-line derived neurotrophic factor in vivo. Eur J Neurosci, Vol. 15, No. 4, pp. 637-643.

Schober, A.; Peterziel, H.; von Bartheld, C.S.; Simon, H.; Krieglstein, K. \& Unsicker, K. (2007). GDNF applied to the MPTP-lesioned nigrostriatal system requires TGF-beta for its neuroprotective action. Neurobiol Dis, Vol. 25, No. 2, pp. 378-391.

Sengle, G.; Charbonneau, N.L.; Ono, R.N.; Sasaki, T.; Alvarez, J.; Keene, D.R.; Bachinger, H.P. \& Sakai, L.Y. (2008). Targeting of bone morphogenetic protein growth factor complexes to fibrillin. J Biol Chem, Vol. 283, No. 20, pp. 13874-13888. 
Sengle, G.; Ono, R.N.; Lyons, K.M.; Bachinger, H.P. \& Sakai, L.Y. (2008). A new model for growth factor activation: type II receptors compete with the prodomain for BMP-7. J Mol Biol, Vol. 381, No. 4, pp. 1025-1039.

Sherer, T.B.; Fiske, B.K.; Svendsen, C.N.; Lang, A.E. \& Langston, J.W. (2006). Crossroads in GDNF therapy for Parkinson's disease. Mov Disord, Vol. 21, No. 2, pp. 136-141.

Shi, Y. \& Massague, J. (2003). Mechanisms of TGF-beta signaling from cell membrane to the nucleus. Cell, Vol. 113, No. 6, pp. 685-700.

Shingo, T.; Date, I.; Yoshida, H. \& Ohmoto, T. (2002). Neuroprotective and restorative effects of intrastriatal grafting of encapsulated GDNF-producing cells in a rat model of Parkinson's disease. J Neurosci Res, Vol. 69, No. 6, pp. 946-954.

Shults, C.W.; Kimber, T. \& Martin, D. (1996). Intrastriatal injection of GDNF attenuates the effects of 6-hydroxydopamine. Neuroreport, Vol. 7, No. 2, pp. 627-631.

Sieber, C.; Kopf, J.; Hiepen, C. \& Knaus, P. (2009). Recent advances in BMP receptor signaling. Cytokine Growth Factor Rev, Vol. 20, No. 5-6, pp. 343-355.

Sinclair, S.R.; Svendsen, C.N.; Torres, E.M.; Martin, D.; Fawcett, J.W. \& Dunnett, S.B. (1996). GDNF enhances dopaminergic cell survival and fibre outgrowth in embryonic nigral grafts. Neuroreport, Vol. 7, No. 15-17, pp. 2547-2552.

Slevin, J.T.; Gerhardt, G.A.; Smith, C.D.; Gash, D.M.; Kryscio, R. \& Young, B. (2005). Improvement of bilateral motor functions in patients with Parkinson disease through the unilateral intraputaminal infusion of glial cell line-derived neurotrophic factor. J Neurosurg, Vol. 102, No. 2, pp. 216-222.

Storm, E.E.; Huynh, T.V.; Copeland, N.G.; Jenkins, N.A.; Kingsley, D.M. \& Lee, S.J. (1994). Limb alterations in brachypodism mice due to mutations in a new member of the TGF beta-superfamily. Nature, Vol. 368, No. 6472, pp. 639-643.

Sullivan, A.M.; Opacka-Juffry, J. \& Blunt, S.B. (1998). Long-term protection of the rat nigrostriatal dopaminergic system by glial cell line-derived neurotrophic factor against 6-hydroxydopamine in vivo. Eur J Neurosci, Vol. 10, No. 1, pp. 57-63.

Sullivan, A.M.; Opacka-Juffry, J.; Hotten, G.; Pohl, J. \& Blunt, S.B. (1997). Growth/differentiation factor 5 protects nigrostriatal dopaminergic neurones in a rat model of Parkinson's disease. Neurosci Lett, Vol. 233, No. 2-3, pp. 73-76.

Sullivan, A.M.; Opacka-Juffry, J.; Pohl, J. \& Blunt, S.B. (1999). Neuroprotective effects of growth/differentiation factor 5 depend on the site of administration. Brain Res, Vol. 818, No. 1, pp. 176-179.

Sullivan, A.M.; Pohl, J. \& Blunt, S.B. (1998). Growth/differentiation factor 5 and glial cell line-derived neurotrophic factor enhance survival and function of dopaminergic grafts in a rat model of Parkinson's disease. Eur J Neurosci, Vol. 10, No. 12, pp. 3681-3688.

Tadimalla, A.; Belmont, P.J.; Thuerauf, D.J.; Glassy, M.S.; Martindale, J.J.; Gude, N.; Sussman, M.A. \& Glembotski, C.C. (2008). Mesencephalic astrocyte-derived neurotrophic factor is an ischemia-inducible secreted endoplasmic reticulum stress response protein in the heart. Circ Res, Vol. 103, No. 11, pp. 1249-1258.

Tai, M.H.; Cheng, H.; Wu, J.P.; Liu, Y.L.; Lin, P.R.; Kuo, J.S.; Tseng, C.J. \& Tzeng, S.F. (2003). Gene transfer of glial cell line-derived neurotrophic factor promotes functional recovery following spinal cord contusion. Exp Neurol, Vol. 183, No. 2, pp. 508-515.

Tang, F.I.; Tien, L.T.; Zhou, F.C.; Hoffer, B.J. \& Wang, Y. (1998). Intranigral ventral mesencephalic grafts and nigrostriatal injections of glial cell line-derived 
neurotrophic factor restore dopamine release in the striatum of 6hydroxydopamine-lesioned rats. Exp Brain Res, Vol. 119, No. 3, pp. 287-296.

Tatarewicz, S.M.; Wei, X.; Gupta, S.; Masterman, D.; Swanson, S.J. \& Moxness, M.S. (2007). Development of a maturing T-cell-mediated immune response in patients with idiopathic Parkinson's disease receiving r-metHuGDNF via continuous intraputaminal infusion. J Clin Immunol, Vol. 27, No. 6, pp. 620-627.

Theofilopoulos, S.; Goggi, J.; Riaz, S.S.; Jauniaux, E.; Stern, G.M. \& Bradford, H.F. (2001). Parallel induction of the formation of dopamine and its metabolites with induction of tyrosine hydroxylase expression in foetal rat and human cerebral cortical cells by brain-derived neurotrophic factor and glial-cell derived neurotrophic factor. Brain Res Dev Brain Res, Vol. 127, No. 2, pp. 111-122.

Tomac, A.; Lindqvist, E.; Lin, L.F.; Ogren, S.O.; Young, D.; Hoffer, B.J. \& Olson, L. (1995). Protection and repair of the nigrostriatal dopaminergic system by GDNF in vivo. Nature, Vol. 373, No. 6512, pp. 335-339.

Tomac, A.; Widenfalk, J.; Lin, L.F.; Kohno, T.; Ebendal, T.; Hoffer, B.J. \& Olson, L. (1995). Retrograde axonal transport of glial cell line-derived neurotrophic factor in the adult nigrostriatal system suggests a trophic role in the adult. Proc Natl Acad Sci U S A, Vol. 92, No. 18, pp. 8274-8278.

Toulouse, A. \& Sullivan, A.M. (2008). Progress in Parkinson's disease-where do we stand? Prog Neurobiol, Vol. 85, No. 4, pp. 376-392.

Treanor, J.J.; Goodman, L.; de Sauvage, F.; Stone, D.M.; Poulsen, K.T.; Beck, C.D.; Gray, C.; Armanini, M.P.; Pollock, R.A.; Hefti, F.; Phillips, H.S.; Goddard, A.; Moore, M.W.; Buj-Bello, A.; Davies, A.M.; Asai, N.; Takahashi, M.; Vandlen, R.; Henderson, C.E. \& Rosenthal, A. (1996). Characterization of a multicomponent receptor for GDNF. Nature, Vol. 382, No. 6586, pp. 80-83.

Trupp, M.; Arenas, E.; Fainzilber, M.; Nilsson, A.S.; Sieber, B.A.; Grigoriou, M.; Kilkenny, C.; Salazar-Grueso, E.; Pachnis, V. \& Arumae, U. (1996). Functional receptor for GDNF encoded by the c-ret proto-oncogene. Nature, Vol. 381, No. 6585, pp. 785-789.

Trupp, M.; Belluardo, N.; Funakoshi, H. \& Ibanez, C.F. (1997). Complementary and overlapping expression of glial cell line-derived neurotrophic factor (GDNF), c-ret proto-oncogene, and GDNF receptor-alpha indicates multiple mechanisms of trophic actions in the adult rat CNS. J Neurosci, Vol. 17, No. 10, pp. 3554-3567.

Tseng, J.L.; Baetge, E.E.; Zurn, A.D. \& Aebischer, P. (1997). GDNF reduces drug-induced rotational behavior after medial forebrain bundle transection by a mechanism not involving striatal dopamine. J Neurosci, Vol. 17, No. 1, pp. 325-333.

Tseng, J.L.; Bruhn, S.L.; Zurn, A.D. \& Aebischer, P. (1998). Neurturin protects dopaminergic neurons following medial forebrain bundle axotomy. Neuroreport, Vol. 9, No. 8, pp. 1817-1822.

Ungerstedt, U. \& Arbuthnott, G.W. (1970). Quantitative recording of rotational behavior in rats after 6-hydroxydopamine lesions of the nigrostriatal dopamine system. Brain Res. Vol. 24, pp. 485-493.

Unsicker, K.; Suter-Crazzalora, C. \& Krieglstein, K. (1996). Growth factor function in the development and maintenance of midbrain dopaminergic neurons: concepts, facts and prospects for TGF-beta. Ciba Found Symp, Vol. 196, No. pp. 70-80; discussion 80-74. 
Voutilainen, M.H.; Back, S.; Peranen, J.; Lindholm, P.; Raasmaja, A.; Mannisto, P.T.; Saarma, M. \& Tuominen, R.K. (2011). Chronic infusion of CDNF prevents 6-OHDA-induced deficits in a rat model of Parkinson's disease. Exp Neurol, Vol. 228, No. 1, pp. 99-108.

Voutilainen, M.H.; Back, S.; Porsti, E.; Toppinen, L.; Lindgren, L.; Lindholm, P.; Peranen, J.; Saarma, M. \& Tuominen, R.K. (2009). Mesencephalic astrocyte-derived neurotrophic factor is neurorestorative in rat model of Parkinson's disease. J Neurosci, Vol. 29, No. 30, pp. 9651-9659.

Wang, L.J.; Lu, Y.Y.; Muramatsu, S.; Ikeguchi, K.; Fujimoto, K.; Okada, T.; Mizukami, H.; Matsushita, T.; Hanazono, Y.; Kume, A.; Nagatsu, T.; Ozawa, K. \& Nakano, I. (2002). Neuroprotective effects of glial cell line-derived neurotrophic factor mediated by an adeno-associated virus vector in a transgenic animal model of amyotrophic lateral sclerosis. J Neurosci, Vol. 22, No. 16, pp. 6920-6928.

Wang, Y.; Tien, L.T.; Lapchak, P.A. \& Hoffer, B.J. (1996). GDNF triggers fiber outgrowth of fetal ventral mesencephalic grafts from nigra to striatum in 6-OHDA-lesioned rats. Cell Tissue Res, Vol. 286, No. 2, pp. 225-233.

Widenfalk, J.; Nosrat, C.; Tomac, A.; Westphal, H.; Hoffer, B. \& Olson, L. (1997). Neurturin and glial cell line-derived neurotrophic factor receptor-beta (GDNFR-beta), novel proteins related to GDNF and GDNFR-alpha with specific cellular patterns of expression suggesting roles in the developing and adult nervous system and in peripheral organs. J Neurosci, Vol. 17, No. 21, pp. 8506-8519.

Widmer, H.R.; Schaller, B.; Meyer, M. \& Seiler, R.W. (2000). Glial cell line-derived neurotrophic factor stimulates the morphological differentiation of cultured ventral mesencephalic calbindin- and calretinin-expressing neurons. Exp Neurol, Vol. 164, No. 1, pp. 71-81.

Winkler, C.; Sauer, H.; Lee, C.S. \& Bjorklund, A. (1996). Short-term GDNF treatment provides long-term rescue of lesioned nigral dopaminergic neurons in a rat model of Parkinson's disease. J Neurosci, Vol. 16, No. 22, pp. 7206-7215.

Wood, T.K.; McDermott, K.W. \& Sullivan, A.M. (2005). Differential effects of growth/differentiation factor 5 and glial cell line-derived neurotrophic factor on dopaminergic neurons and astroglia in cultures of embryonic rat midbrain. J Neurosci Res, Vol. 80, No. 6, pp. 759-766.

Xing, B.; Xin, T.; Zhao, L.; Hunter, R.L.; Chen, Y. \& Bing, G. (2010). Glial cell line-derived neurotrophic factor protects midbrain dopaminergic neurons against lipopolysaccharide neurotoxicity. J Neuroimmunol, Vol. 225, No. 1-2, pp. 43-51.

Yamashita, H.; Ten Dijke, P.; Heldin, C.H. \& Miyazono, K. (1996). Bone morphogenetic protein receptors. Bone, Vol. 19, No. 6, pp. 569-574.

Yasuhara, T.; Shingo, T.; Muraoka, K.; Kobayashi, K.; Takeuchi, A.; Yano, A.; Wenji, Y.; Kameda, M.; Matsui, T.; Miyoshi, Y. \& Date, I. (2005). Early transplantation of an encapsulated glial cell line-derived neurotrophic factor-producing cell demonstrating strong neuroprotective effects in a rat model of Parkinson disease. J Neurosurg, Vol. 102, No. 1, pp. 80-89.

Yu, T.; Scully, S.; Yu, Y.; Fox, G.M.; Jing, S. \& Zhou, R. (1998). Expression of GDNF family receptor components during development: implications in the mechanisms of interaction. J Neurosci, Vol. 18, No. 12, pp. 4684-4696. 
Yurek, D.M. (1998). Glial cell line-derived neurotrophic factor improves survival of dopaminergic neurons in transplants of fetal ventral mesencephalic tissue. Exp Neurol, Vol. 153, No. 2, pp. 195-202.

Zhang, Z.; Miyoshi, Y.; Lapchak, P.A.; Collins, F.; Hilt, D.; Lebel, C.; Kryscio, R. \& Gash, D.M. (1997). Dose response to intraventricular glial cell line-derived neurotrophic factor administration in parkinsonian monkeys. J Pharmacol Exp Ther, Vol. 282, No. 3, pp. 1396-1401.

Zurn, A.D.; Widmer, H.R. \& Aebischer, P. (2001). Sustained delivery of GDNF: towards a treatment for Parkinson's disease. Brain Res Brain Res Rev, Vol. 36, No. 2-3, pp. 222-229. 


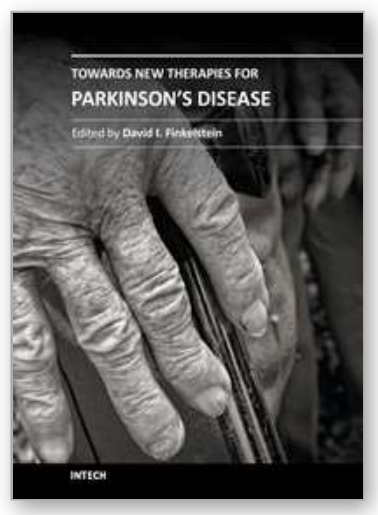

\section{Towards New Therapies for Parkinson's Disease}

Edited by Prof. David Finkelstein

ISBN 978-953-307-463-4

Hard cover, 396 pages

Publisher InTech

Published online 02, November, 2011

Published in print edition November, 2011

Parkinson's disease (PD) is characterised clinically by various non-motor and progressive motor symptoms, pathologically by loss of dopamine producing cells and intraneuronal cytoplasmic inclusions composed primarily of ?-synuclein. By the time a patient first presents with symptoms of Parkinson's disease at the clinic, a significant proportion of the cells in the substantia nigra have already been destroyed. This degeneration progresses despite the current therapies until the cell loss is so great that the quality of normal life is compromised. The dopamine precursor levodopa is the most valuable drug currently available for the treatment of PD. However for most PD patients, the optimal clinical benefit from levodopa decreases around five to six years of treatment. The aim of the chapters of this book is to work towards an understanding in the mechanisms of degeneration and to develop disease modifying therapies.

\section{How to reference}

In order to correctly reference this scholarly work, feel free to copy and paste the following:

Aideen M. Sullivan and André Toulouse (2011). The Potential of Neurotrophic Factors for the Treatment of Parkinson's Disease, Towards New Therapies for Parkinson's Disease, Prof. David Finkelstein (Ed.), ISBN: 978-953-307-463-4, InTech, Available from: http://www.intechopen.com/books/towards-new-therapies-forparkinson-s-disease/the-potential-of-neurotrophic-factors-for-the-treatment-of-parkinson-s-disease

\section{INTECH}

open science | open minds

\author{
InTech Europe \\ University Campus STeP Ri \\ Slavka Krautzeka 83/A \\ 51000 Rijeka, Croatia \\ Phone: +385 (51) 770447 \\ Fax: +385 (51) 686166 \\ www.intechopen.com
}

\author{
InTech China \\ Unit 405, Office Block, Hotel Equatorial Shanghai \\ No.65, Yan An Road (West), Shanghai, 200040, China \\ 中国上海市延安西路65号上海国际贵都大饭店办公楼 405 单元 \\ Phone: +86-21-62489820 \\ Fax: +86-21-62489821
}


(C) 2011 The Author(s). Licensee IntechOpen. This is an open access article distributed under the terms of the Creative Commons Attribution 3.0 License, which permits unrestricted use, distribution, and reproduction in any medium, provided the original work is properly cited. 